
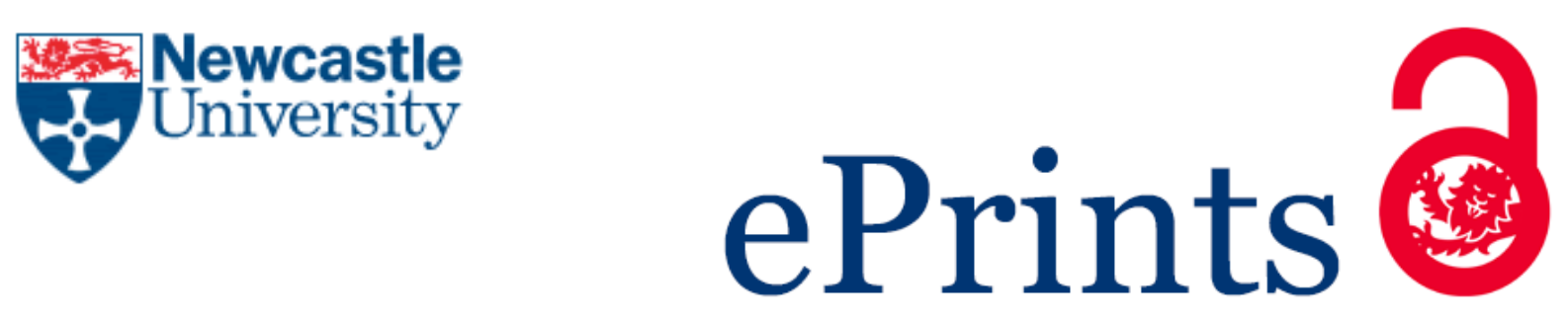

Briggs KM, Loveridge FA, Glendinning S.

Failures in transport infrastructure embankments.

Engineering Geology 2016

DOI: http://dx.doi.org/10.1016/j.enggeo.2016.07.016

\title{
Copyright:
}

(C) 2016. This manuscript version is made available under the CC-BY-NC-ND 4.0 license

DOI link to article:

http://dx.doi.org/10.1016/i.enggeo.2016.07.016

Date deposited:

$25 / 08 / 2016$

Embargo release date:

02 August 2017

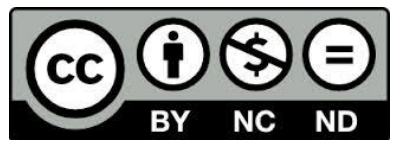

This work is licensed under a

Creative Commons Attribution-NonCommercial-NoDerivatives 4.0 International licence 
25 July 2016

\section{Failures in transport infrastructure embankments}

Briggs K. M., Loveridge F. A., Glendinning, S.

Dr Kevin M Briggs (Corresponding author)

BEng EngD FHEA

Lecturer in Geotechnical Engineering

Department of Architecture and Civil Engineering

University of Bath

Claverton Down

Bath BA2 7AY

Tel: 01225386269

E-mail: k.m.briggs@bath.ac.uk

Dr Fleur A Loveridge

MSc PhD FGS CGeol CEng MICE

Royal Academy of Engineering Research Fellow

Faculty of Engineering and Environment

University of Southampton

University Road

Southampton SO17 1BJ

Tel: 02380592662

E-mail: fleur.loveridge@,soton.ac.uk

Professor Stephanie Glendinning

BSc PhD

Professor of Civil Engineering 
School of Civil Engineering and Geosciences

Newcastle University

Newcastle upon Tyne NE1 7RU

Tel: 01912086612

E-mail: stephanie.glendinning@ncl.ac.uk

Word count: 7555

Number of figures: 12

Number of tables: 3

Keywords: Embankments; Railway; Highway; Failure; Shrink-swell

Highlights:

- Typical failure mechanisms differ for highway and railway embankments

- Pore water pressure increase affects both highway and railway embankments

- Some railway embankments are susceptible to deformation and progressive failure

- Embankment risk factors have been identified empirically but are poorly understood 
14 July 2016

\title{
Failures in transport infrastructure embankments
}

\begin{abstract}
To ensure that road and rail transport networks remain operational, both highway and railway embankments require continual maintenance and renewal to mitigate against ongoing deterioration and repair any sections damaged by realised failures. This paper provides a review of recent developments in the understanding of highway and railway embankment degradation and failure. Failures due to pore water pressure increase, seasonal shrink-swell deformation and progressive failure are considered. The material composition and construction of highway and railway embankments differ, which influences the dominant type and timing of embankment failure. There is evidence for highway embankment failures induced by pore water pressure increase, but not seasonal deformation and progressive failure. Some railway embankments are susceptible to pore water pressure increase, seasonal shrink-swell deformation and progressive failure due to the age and nature of the dumped clay fill used in their construction. The approaches used to measure and explore embankment failure mechanisms are compared and discussed. Field observations have been used to understand pore water pressure increase and seasonal shrink-swell deformation in embankments, while the investigation of progressive embankment failure has mainly utilised physical and numerical modelling approaches. Further field and laboratory investigation is required before the rigorous analysis of embankment failure can be routinely undertaken. However, progress is being made to empirically identify and evaluate the various risk factors affecting transport infrastructure embankment failure.
\end{abstract}




\section{Introduction}

Transport infrastructure embankments consist of fill material placed to maintain the vertical alignment of road, rail and canal routes by raising their level above that of the surrounding natural ground. They are distinct from cuttings, which reduce the ground level by excavating in situ soil and rock. There are approximately $9,660 \mathrm{~km}$ of embankments in the UK owned by the four main infrastructure owners Network Rail (5,000km), Highways England (Formerly Highways Agency; 3,500 km), British Waterways (1,100 km) and London Underground Ltd (60 km) (Perry et al., 2003).

Embankment failures occurred both during and shortly after embankment construction during the expansion of the railway in the 1800s (Skempton, 1996). Highway embankment slope failures were reported to affect about 7 per cent of the highway network in the 1960s (Symons, 1970), following their first construction in 1958 (Perry et al., 2003). The failure of both highway and railway embankments requires continual maintenance and repair to be undertaken by infrastructure owners. For example, the maintenance of railway earthworks (embankments and cuttings) including refurbishment, renewal and vegetation clearance cost $£ 90$ million per annum in the UK between 2006 and 2012 (Arup, 2013). The repair of highway embankment and cutting slopes cost approximately $£ 20$ million per annum in the UK in 2010 (Arup, 2010). Embankments form half of all earthworks (cuttings and embankments) by asset length (Perry et al., 2003) and represent a significant proportion of the maintenance cost incurred by infrastructure owners. However, embankments have not received the same attention in the literature as cut slopes (e.g. Chandler \& Skempton, 1974; Potts et al., 1997; Cooper et al., 1998; Leroueil, 2001; Vaughan et al., 2004).

This paper provides a review of recent developments in the understanding of highway and railway embankment degradation and failure. The differing construction methods and 
performance requirements of these embankments are described. The approaches used to measure and explore embankment failure mechanisms are compared and discussed, including field observations, centrifuge modelling, finite element modelling.

Scope of the review

This review describes slope failures in highway and railway infrastructure embankments, with an emphasis on failure of the embankment fill. The review does not include the failure of cut slopes (Leroueil, 2001), embankments on extensive soft ground (Chai et al., 2002; Lehtonen et al., 2015) or water retaining embankments such as canal embankments (Perry et al., 2003) and embankment dams (Vaughan et al., 2004; Charles \& Bromhead, 2008; Lees et al., 2013), which have received attention elsewhere in the literature. The review considers embankment failures due to the influence of weather and long term deterioration but does not consider failures where transport embankments intentionally or accidently act as coastal or fluvial flood defences (e.g. Sharp et al., 2013).

\section{The design and construction of highway and railway embankments}

A timeline of embankment construction in the UK is shown in Table 1 (adapted from Perry et al., 2003). The differing construction methods and material composition of highway and railway embankments (Figure 1) reflect the contemporary availability of construction materials, material specification and construction plant, as well as the experience and geotechnical understanding of the designers.

Early railway embankments were built empirically and were not designed in the context of modern soil mechanics (e.g. Harrison, 1881). The large scale construction of railway embankments began in 1827 with the construction of the Liverpool and Manchester Railway. Between 1834 and 1841 nine main lines of railway were built in England covering over 660 
miles (Skempton, 1996). This required the excavation of 54 million $\mathrm{m}^{3}$ of material, most of which was used to construct embankments. Skempton (1996) described how clay was excavated and transported from nearby cuttings and then tipped onto the natural ground surface (Figure 2) to form an embankment of heterogeneous, poorly compacted, 'dumped' clay fill (Vaughan et al., 2004). The foundation was not prepared prior to embankment construction, with topsoil and any soft superficial deposits usually being left in place. The extensive excavation and investigation of fills carried out as part of remediation works have revealed that dumped clay fills have a clod-matrix structure which differs from compacted, engineered fill or natural clay (Figure 3; O’Brien, 2007). Intact clods of clay influence the compressibility and shear modulus of the dumped clay fill while a matrix of remoulded clay and foreign matter (silt, sand, gravel) influences the shear strength and the permeability (O'Brien, 2004; O'Brien, 2007).

By the mid 1830s, embankments were rapidly constructed by end-tipping fill from the advancing head of an embankment to its full height, rather than constructed in shallow layers to allow consolidation of the embankment and foundation (Skempton, 1996). Early main line railway embankments were often constructed at a slope gradient of 1:2 (vertical: horizontal) to between $2 \mathrm{~m}$ and $8 \mathrm{~m}$ high (O'Brien, 2013), with slope gradients up to 1:1.5 and embankment heights up to $16 \mathrm{~m}$ described by Skempton (1996). The shape of these embankments was quite variable. Some embankments had a steep, uniform slope while others had a 'coat-hanger' appearance with an over-steepened upper slope and a shallower lower slope (Figure 1; O'Brien, 2013).

In contrast to railway embankments, the design of highway embankments benefitted from experience gained during railway construction, from the development of modern soil mechanics and from an improved understanding of the soils used in construction. An understanding of the properties of fill soils and their placement was developed early in 
motorway construction, based on research at the Road Research Laboratory (1952). Highway embankments were constructed to modern standards (e.g. British Standard 6031 (British Standards Institution, 2009)) on a prepared foundation with installed drainage and regular slope profiles (Figure 1). The selection, placement and compaction of the fill material was specified to produce a largely homogeneous engineered fill with a consistent density, strength, stiffness and permeability (Highways Agency, 2009).

Highway embankment construction to motorway standard began with the Preston By-Pass, which opened in December 1958 (Perry, 2003). This marked the beginning of a rapid growth in highway embankment construction between the 1960s and 1990s (Loveridge et al., 2010). By 1994, 92\% of the current motorway network had been built (Wootton, 2010). Highway embankments built to motorway standard were required to maintain a low gradient ( $4 \%$ or 1 in 25) over long distances for high-speed traffic. They differed from earlier roads which followed the natural contours of the ground and differed from road embankment construction on sidelong ground early in the industrial revolution (Vaughan et al., 2004). A survey of $570 \mathrm{~km}$ of the motorway network in England and Wales between 1980 and 1988 (21\% coverage of the network in 1987) showed that most ( $>50 \%)$ highway embankment slopes were constructed at a slope gradient of 1:2 (vertical: horizontal) and that $86 \%$ of embankments were less than $5 \mathrm{~m}$ high (Perry, 1989). Only 6\% of the surveyed embankment length was greater than $7.5 \mathrm{~m}$ high.

Highway embankments were designed using limit equilibrium methods assuming classical saturated soil mechanics and simple constitutive models. However, this has not eliminated the risk of embankment failure as many processes relevant to actual failure mechanisms relate to the unsaturated behaviour of soils and rely on the use of complex constitutive models.

\section{Performance requirements and the observed failure of highway and railway embankments}


Embankments must meet performance requirements when supporting overlying transport (road and rail) infrastructure. For example, highway embankments must satisfy ride quality requirements which are based on the variance of a profile level relative to a datum derived from a moving average (Perry, 2003). Railway embankments must satisfy ride safety and track quality requirements for a specified line speed and loading (Perry, 2003). The failure to meet performance requirements can range from an ultimate limit state failure, which may halt or severely restrict traffic flow, to a serviceability limit state failure which does not disrupt traffic flow but prevents the embankment from operating as intended (Perry, 2003). In terms of limit state design, failure by any mode is termed reaching or exceeding an 'ultimate limit state' when soil rupture is caused by shear stresses in the embankment exceeding the shear strength of the soil (Burland, 2012). In terms of limit state design, excessive deflection involves breaching a 'serviceability limit state', where excessive soil movement or deformation occurs. In some cases, but not in all cases, a serviceability failure may be linked to an ultimate limit failure in embankments (e.g. excessive deflection may precede a shear failure).

Typical failure modes and mechanisms differ between highway and railway embankments due to their different construction methods and construction materials. Ultimate limit state failures during motorway embankment construction were infrequent. When they did occur they were usually deep seated rotational failures which were typically caused by the presence of weak foundation soils (Greenwood et al., 1985). However shallow rotational and translational slope failures continued to occur on the side slopes of motorway earthworks post-construction (Figures $4 \mathrm{a} \& 4 \mathrm{~b})$. This affected $17 \mathrm{~km}$ of embankment slope over $570 \mathrm{~km}(3 \%)$ of surveyed motorway network across England and Wales by 1988 (Perry, 1989). This extensive survey of highway embankment slopes aged between 1 year and 25 years old showed that shallow failure surfaces rarely exceeded $1.5 \mathrm{~m}$ depth below the ground surface (95\% of occurrences). Individual failure surfaces were often less than $20 \mathrm{~m}$ long, but could join together and regress 
to the top of an embankment slope to produce longer lengths. This was particularly common in steep and high embankments constructed from high-plasticity over-consolidated clays (e.g. Gault, Kimmeridge, Oxford and London Clays) or in combined foundation geologies such as Glacial Gravel overlying Middle Lias Clay.

Foundation failures in weak or weathered clay soils sometimes occurred during railway embankment construction (Cooper, 1899; Vaughan et al., 2004). Failures within the body of large embankments (in excess of $6 \mathrm{~m}$ to $7 \mathrm{~m}$ height) occurred during and soon after construction (Squire, 1880; O’Brien, 2007), which Skempton (1996) attributed to weakening and softening of the dumped clay fill clods by absorption of rain water. Post-construction settlements and failures were corrected by adding granular material (often locomotive ash or ballast) to the top of the embankments (O'Brien, 2007). As a result of the construction process, railway embankments often contain hidden defects including old shear surfaces from historic instability, localised high permeability sand lenses and remnants of topsoil/alluvium at the foundation of the embankment (O'Brien, 2013).

The ultimate limit, 'delayed failure' of railway embankments continued long after construction (O'Brien, 2007). Delayed failures are often deep seated rotational slips, with a failure surface exceeding $2 \mathrm{~m}$ depth and a shape which is largely determined by the composition of the embankment fill and the underlying ground. These mainly occur where over-consolidated clays form the main material constituent of the embankment, rather than in embankments constructed of granular material (Perry, 2003). The failure surface may be present at the embankment crest (Figure 5a) and extend beyond the slope toe, extend into the foundation material or may be entirely contained within the embankment slope (Perry, 2003; O’Brien, 2007). There are detailed case studies of deep seated railway embankment failures in the literature (e.g. Gellatley et al., 1995; Andrei, 2000; Martin, 2000; Birch \& Dewar, 2002; O’Kelly, 2008; Li et al., 2014) and reports of ultimate limit embankment failures can be found in news articles, owing in part 
to the disruption caused to overlying railway traffic (e.g. Ground Engineering, 1995; Ground Engineering, 2014a, Ground Engineering, 2014b).

The movement and deformation of railway embankments can constitute a serviceability failure affecting the line and level of the track. Such track deformation may require trains to operate at a reduced speed in order to maintain ride quality and ensure passenger safety, but would not require closure of the railway line. Typically, differential settlement of the outer rail must be limited to 1:500 (+/- $20 \mathrm{~mm})$ along a $10 \mathrm{~m}$ interval of track (Perry et al., 1999). Loosely tipped, high-plasticity clay fill embankments can undergo significant volume change in excess of allowable settlement limits, causing significant disruption and delay to railway traffic (Loveridge et al., 2010). Railway embankment deformation and differential railway track movement has been closely linked to seasonal weather conditions and the presence of lineside vegetation. Instrumentation installed on LUL earthworks have shown up to $+/-50 \mathrm{~mm}$ of vertical seasonal track movement (Andrei, 2000) and embankment movement (Scott et al., 2007), with the largest movements in the vicinity of mature trees. Vertical heave movements have been reported close to recently felled trees, including $35 \mathrm{~mm}$ of heave adjacent to a felled Willow tree on a clay fill LUL embankment (Briggs et al., 2013b) and up to $68 \mathrm{~mm}$ vertical heave and $63 \mathrm{~mm}$ of lateral heave on a clay fill Network Rail embankment in Essex (Smethurst et al., 2015).

\section{Failure mechanisms in highway and railway embankments}

Several failure mechanisms have been reported and postulated in the literature for highway and railway embankments. These include (i) pore water pressure increase and equilibration (ii) seasonal shrink-swell deformation and (iii) progressive embankment failure (Hughes, et al., 2009; O'Brien, 2013). They are inter-related and may act together in combination or sequentially (e.g. shrink-swell deformation may lead to progressive failure of the embankment, 
with the final rupture triggered by an increase in pore water pressure). The first of these failure mechanisms occurs in both highway and railway embankment slopes, often as shallow slope failures (Figure 5b) but sometimes as deeper seated failures. The second and last of these failure mechanisms are associated with excessive deformation and deep-seated failure surfaces in railway embankments, but much less so in highway embankments (Table 2).

\section{Pore water pressure induced failure of highway and railway embankments}

Pore water pressure increase and equilibration refers to changes in effective stress due to surface water infiltration or the loss of soil suction within embankments. The initial pore water pressure conditions within highway embankments and railway embankments are likely to have differed. Railway embankments constructed from loosely compacted, heterogeneous fill were likely to have variable (positive and negative) pore water pressures within the embankment core whereas pore water pressures were likely to be lower and more uniform within highway embankments constructed from homogeneous engineered fill. In both types of embankment, an increase in pore water pressure (and hence effective stress reduction) in excess of historic values can reduce the shear strength of the soil within an embankment and trigger a slope failure. Rainfall-induced pore water pressure increases within the soil near the slope surface can trigger a shallow slope failure. Such a rainfall-induced, shallow failure slope failure mechanism is well documented in natural unsaturated slopes around the world, including in Italy, USA, Brazil and Hong Kong (Leroueil, 2011; Zhang et al., 2011). Increased pore water pressures can also trigger the deep seated failure of embankments that have been weakened by progressive failure or old shear surfaces from historic instability.

Pore water pressure increase is often mitigated in highway embankment design. This includes the use of drainage measures to remove water from the road and the use of low permeability fill to encourage surface water run-off. However cracks in the road surface and damaged 
drainage may lead to water concentration and the development of positive pore water pressures (Anderson \& Kneale, 1980b; Perry et al., 2003). Anderson et al., (1982) showed that the formation of shrinkage cracks during the summer months can facilitate rapid water entry during subsequent wet weather. This allowed positive pore water pressures to develop at shallow depth and trigger a shallow failure immediately adjacent to an instrumented highway slope (Anderson \& Kneale, 1980a). Rapid pore water pressure increase in response to wet weather was also measured at the toe of Otford Trial Embankment prior to failure along the full length of the 10.6m high, Gault Clay embankment in 1970 (Garrett \& Wale, 1985).

Railway embankments are susceptible to rainfall-induced pore water pressure increase and the shear failure of the embankment slope (Figure 5b). For this reason, slope drainage has long been recognised as an important slope remediation measure (Birch \& Dewar, 2002). Loveridge et al., (2010) showed that five times as many major railway delay incidents ( $>8 \mathrm{~h}$ duration) due to geotechnical causes occurred in the winter months (242 incidents) than in the summer months (44 incidents) across all Network Rail territories between 2000 and 2003. The delays were attributed to the ultimate failure of earthworks driven by elevated pore water pressures or washout. Ultimate limit state failures in Networks Rail's South East Territory (SET) were also correlated with monthly winter rainfall in excess of the 1971-2000 long-term average (LTA). Maximum monthly rainfall close to $200 \%$ of the LTA in the winters of $2000-2001,2001-2002$ and 2006-2007 correlated with more than thirty, ten and a further ten failures in the region respectively. Supporting hydrological modelling by Loveridge et al., (2010) showed that the increased permeability of railway embankments (often greater than $5 \times 10^{-8} \mathrm{~ms}^{-1}$ ) relative to highway embankments (often less than $1 \times 10^{-8} \mathrm{~ms}^{-1} \mathrm{~s}$ ) made railway embankments more susceptible to rainfall infiltration, the development of significant wetting fronts and raised pore water pressure during wet winter weather. Surface run-off was more likely in highway embankments, which are of lower permeability (except at the very near surface). 
The influence of age, fill permeability and construction quality on highway and railway embankments was compared on a full scale, instrumented embankment model using controlled experiments over a four year period (Toll et al., 2013; Glendinning et al., 2014; Gunn et al., 2015). The model embankment was constructed from glacial till fill on a stiff glacial till foundation, with test plots compacted to different densities and with different surface capping layers (granular or asphalt). The experiments showed that the permeability and soil water retention behaviour of fill materials has a critical influence on the magnitude and distribution of pore water pressures in response to changing climate and weather events. Significant differences in pore water pressure behaviour were observed between a well-compacted (1.7 $\mathrm{Mg} / \mathrm{m}^{3}$ ) plot with an asphalt capping layer (i.e. a highway embankment) and a poorlycompacted $\left(1.6 \mathrm{Mg} / \mathrm{m}^{3}\right)$ test plot with a coarse granular capping layer (i.e. a railway embankment). The largest pore water pressure and in situ fill permeability variations occurred within the 'near surface zone' (up to $1.5 \mathrm{~m}$ depth) of both the well-compacted and poorlycompacted plots.

In situ piezometer measurements have shown pore water pressure increases during extremely wet weather. Ridley et al., (2004) showed raised pore water pressures towards a hydrostatic condition in instrumented LUL embankments in March 2001, following the wet winter of 2000-2001 (from a total of 113 piezometers). At the time (March 2001) this was the wettest winter in the UK since records began in 1766 (Birch \& Dewar, 2002), during which there were approximately 100 slope failures across the railway network and 60 reported highway slope failures (embankments and cuttings; Turner, 2001). Further interpretation of the Ridley et al., (2004) data by Briggs et al., (2013) showed a correlation between raised pore water pressures and the permeability of the embankment foundation soil (Figure 6). Pore water pressures increased towards hydrostatic in clay fill embankments founded on London Clay, while pore water pressures did not exceed $10 \mathrm{kPa}$ in clay fill embankments underdrained by a more 
permeable foundation soil (e.g. chalk or river terrace deposits), despite the extremely wet winter weather.

The seasonal deformation and serviceability failure of highway and railway embankments

Serviceability failure due to soil deformation is well documented in railway embankments but is rarely encountered in highway embankments. Loveridge et al., (2010) showed that the in situ permeability of railway clay fill lies close to a critical range $\left(1 \times 10^{-7} \mathrm{~ms}^{-1}\right)$ corresponding to likely rainfall rates in the UK (average $5 \mathrm{~mm}^{\text {day }}{ }^{-1}$ ). This makes railway embankments more sensitive to rainfall events and significant wetting fronts than highway embankments, which are much less permeable and hence subject to greater surface runoff. The related seasonal movement and deformation of railway embankments is both more likely to occur and has the potential to be more complex than in highway embankments. Recent field observations have been used to identify and understand the underlying causes and mechanisms of failure, which are described below (O’Brien 2007; Loveridge et al., 2010; Briggs et al., 2013b; Smethurst et al., (2015)).

Analyses of network-level datasets of embankment performance (Loveridge et al., 2010) showed that train delay minutes owing to geotechnical causes during the dry summer months are primarily located in areas of high-plasticity soil, with almost two orders of magnitude more delays being attributed to these soils than areas of lower plasticity soils. This was interpreted as being due to the shrink-swell deformation of embankments, leading to track defects and hence speed restrictions. An example of seasonal shrink-swell track movement attributed to embankment serviceability failure is shown in railway track monitoring data from a LUL embankment (Figure 7; Scott et al., 2007). Scott et al., (2007) showed track settlement during the summer months, reaching a minimum by September, and heave movement during the winter months, reaching a maximum in April. 
Instrumented embankment slopes have been used to identify relationships between seasonal weather, soil water content and embankment movement (Scott et al., 2007; O’Brien, 2013; Glendinning et al., 2014; Smethurst et al., 2015). Scott et al., (2007) showed that the seasonal deformation of a high-plasticity clay fill embankment correlated to changes in the surface water balance and soil water content, as indicated by a soil moisture deficit (SMD) calculation (e.g. Smethurst et al., 2006). Winter heave of the embankment occurred during periods of low (zero) SMD while embankment settlement occurred during periods of high $(>300 \mathrm{~mm})$ SMD in the summer months. The amplitude of shrink-swell movement adjacent to Oak and Poplar tree covered parts of the slope $(50-55 \mathrm{~mm})$ was an order of magnitude greater than that adjacent to grass covered parts of the slope $(5-8 \mathrm{~mm})$ (Figure 7$)$. Piezometer measurements indicated higher suctions (up to $-90 \mathrm{kPa}$ ) and a greater range of seasonal pore water pressure variation $(80 \mathrm{kPa})$ in the Oak and Poplar tree covered parts of the embankment than in the grass covered parts (20 kPa variation). Glendinning et al., (2009) attributed the high effective stress (up to $500 \mathrm{kPa}$ ) measured in undisturbed samples of Gault clay embankment fill to high suctions induced by adjacent Oak and Hawthorn trees. A study of thirteen LUL railway embankments (Briggs et al., 2013b) showed that large seasonal track movements ( $>10 \mathrm{~mm})$ correlated with the presence (and removal) of Oak, Willow, Poplar and Hawthorn tree species located within a certain tree distance $\left(\mathrm{D}_{\mathrm{t}}\right)$ and tree height $\left(\mathrm{H}_{\mathrm{t}}\right)$ ratio of the track. However other tree species (e.g. Ash, Beech Sycamore) did not show this effect. Tree species were categorised as high, medium or low water demand (Table 2) using the Biddle (1998) classification, reflecting their zone of influence $\left(\mathrm{D}_{t}\right)$ on track movement relative to the tree height $\left(\mathrm{H}_{t}\right)$. These empirical relationships between climate, vegetation and embankment movement provide useful indicators of embankment performance for risk assessment and management. However, reliable analytical descriptions of the effects of trees on embankment movement are not yet established. 
Damaging deformations due to seasonal shrinkage and swelling can be reduced by removing high water demand tree species (Oak, Willow, Poplar and Hawthorn) from embankment slopes. However, this can have long term serviceability implications that need to be considered, as well as increase the risk of ultimate limit state failure due to loss of suctions within the soil. Detailed observations of tree influence on embankment pore water pressures and deformation have been obtained from instrumented embankment sites from where trees have subsequently been removed. Smethurst et al., (2015) obtained five years of in situ measurements showing pore water pressure changes, moisture content changes and slope displacements within a vegetated embankment during the removal of mature trees (Oak and Ash) from the embankment slopes. Measurements showed that mature trees on the embankment slope established permanent soil suctions throughout the year below $2 \mathrm{~m}$ depth. Removal of the trees from the embankment slope altered the surface water balance of wetting and drying, causing the embankment to rewet and the persistent suctions to be lost. Extensometer measurements of vertical embankment displacement showed a reduction in shrink-swell movements at the embankment crest following tree removal. However swelling of the clay fill and heave of the embankment slope continued over a period of at least four years. Measured displacements compared well with displacements calculated from changes in soil volumetric moisture content measured using a neutron probe (Smethurst et al., 2015). The extensometer measurements also broadly compared with estimates of soil heave using pore water pressure data and a one dimensional settlement/heave calculation based on a linear swelling index (Briggs et al., 2013b). Smethurst et al., (2015) suggest that the balance between reducing seasonal track movement and maintaining embankment stability might best be achieved by selectively removing high water demand tree species within a defined distance of influence (e.g. Briggs et al., 2013b), rather than clearing all trees from an embankment slope. 
The seasonal, shrink-swell volume change of railway embankments has been shown to reduce the strength of the clay fill soil and promote the progressive failure of embankment slopes (Potts \& Zdravkovic, 1999; Kovacevic et al., 2001; O’Brien, 2007; Rouainia et al., 2009; O’Brien, 2013). Highway embankments are not subjected to the same cycles of pore water pressure or shrink-swell volume change as railway embankments due to the lower permeability of the fill material used in construction. They are also much less aged than railway embankments, and possibly as a result, there is limited evidence for the progressive failure of highway embankments. Observations of deformed railway embankment profiles indicate a progressive failure mechanism (e.g. O'Brien, 2013) but well instrumented, in situ observations of real-time progressive railway embankment failure are not available in the literature.

The process of progressive failure was confirmed by direct observations of an instrumented cut slope in Selborne (UK), brought to failure by Cooper et al., (1998). Leroueil (2001) shows field evidence for soil weakening and a progressive failure mechanism in natural slopes in Maskinongé (Canada), La Baie (Canada) and Chieti (Italy). However the progressive failure of railway embankment slopes is not well understood and may differ from that in natural and cut slopes due to different initial strain conditions and subsequent strain cycles. For example, embankment slopes would not have an initial strain concentration at the toe due to unloading, and seasonal pore water pressure cycling is greater in some embankments (e.g. dumped clay fill railway embankments) than that in the lower permeability soils of natural and cut slopes. However, a progressive failure mechanism has been characterised by numerical and physical models of embankment wetting and drying.

Models of progressive failure in railway embankments include a strain-softening MohrCoulomb failure criterion to simulate the post-peak reduction in clay fill shear strength towards post-rupture and then residual strength in response to increasing strain. These have largely involved the use of the Imperial College Finite Element Program (ICFEP) (Potts \& Zdravkovic, 
1999; Kovacevic et al., 2001; Nyambayo et al., 2004) or Fast Lagrangian Analysis of Continua (FLAC) (Itasca, 1999; Scott et al., 2007; O’Brien, 2007; Rouainia et al., 2009; O’Brien, 2013). The simulations showed that the accumulation of plastic strain and hence strength degradation occurred in response to changes in effective stress induced by changes in pore water pressure. Simulations of railway embankments showed that a failure surface first developed at the slope toe and then propagated along a sub horizontal surface towards the embankment core (O'Brien, 2013). At failure, the clay fill was close to residual strength at the slope toe but close to peak strength at the embankment crest. This indicated the non-uniform mobilisation of strength along the failure surface, as recognised by Terzaghi and Peck (1947). The simulations are supported by field observations of a ratcheting-type deformation mechanism of outward horizontal slope displacement during the winter months being only partially recovered during the summer months (O'Brien, 2013). O'Brien (2013) attributed this mechanism to the 'coat hanger' shape of some railway embankment slopes (e.g. Earlswood, Sussex (Birch \& Dewar, 2002)).

The deep-seated failure mechanism identified in the simulations was also shown in centrifuge tests of overconsolidated kaolin clay embankment slopes. Take \& Bolton (2011) showed that dilatation and regional softening of the soil in a $1 / 60^{\text {th }}$ scale centrifuge model occurred in response to cyclic variations in effective stress induced by wetting and drying at the slope surface. The dilation and softening was observed to accompany creep in the form of downslope ratcheting, leading to localised ultimate failure at the toe of the slope (Figure 8). Slope displacements in response to cyclic loading were predominately vertical at the slope crest and almost entirely in the horizontal direction at the slope toe. The behaviour of the overconsolidated kaolin clay embankment model (Take \& Bolton, 2011) can be contrasted with that of a compacted fill, glacial till (intermediate plasticity) centrifuge embankment model (Hudacsek et al., 2009). Hydraulic cycles applied to the glacial till fill $1 / 60^{\text {th }}$ scale centrifuge 
embankment model caused decreasing soil movement and progressive failure was not observed. More than 19 years of simulated wetting and drying did not generate significant shrinkage and swelling movement, with displacement trajectories generally orientated downslope (Figure 8). This result was suggested to be more typical of real embankment behaviour for fills of low to intermediate plasticity (Hudacsek et al., 2009).

Numerical and physical models have shown that cyclic loading and strain-softening of the soil can lead to progressive embankment failure. The cyclic loading is induced by pore water pressure variation within the embankment, driven by wetting and drying of the soil surface. Research has focussed on the hydraulic factors controlling and influencing the magnitude and extent of pore water pressure variation within embankments, in order to estimate the time related to the number of cycles to failure. The number of 'cycles to failure' shown by the numerical simulations are comparative only, as the result is dependent on factors such as the mesh size and the boundary conditions applied during each cycle.

Kovacevic et al., (2001) used ICFEP (Potts \& Zdravkovic, 1999) to simulate swelling and consolidation of a diagnostic (i.e. a theoretical but broadly representative) railway embankment during construction and then during shrink-swell cycles towards progressive failure. Embankment pore water pressures were allowed to reach equilibrium with a surface hydraulic boundary condition of $0 \mathrm{kPa}$ during cycles of swelling and between $-5 \mathrm{kPa}$ and $-20 \mathrm{kPa}$ during cycles of shrinkage. The simulation showed that displacement of the embankment was primarily due to plastic yield rather than elastic deformation, that the stiffness of the fill had little influence on the number of cycles to failure and that the failure always occurred along the same rupture surface (Figure 9). This result was explored by O'Brien (2013) for an embankment soil profile that was more representative of the heterogeneous nature of clay fill in Network Rail embankments. O'Brien (2013) showed that the number of cycles to progressive failure in a poorly drained, intermediate plasticity clay fill embankment reduced 
from 33 cycles to 7 cycles with the inclusion of a thin layer $(0.5 \mathrm{~m})$ of more compressible alluvium below the clay fill. The inclusion of the alluvium layer (or any other heterogeneity) led to the concentration of strain in this layer and prevented shear resistance from mobilising elsewhere in the embankment fill.

While the Kovacevic et al., (2001) simulation did not relate to realistic pore water pressure cycles observed within embankments, it showed that the number of cycles to progressive failure increased with the magnitude of the suction boundary condition applied during the shrinkage cycle (up to -20 kPa). Nyambayo et al., (2004) used a similar ICFEP embankment model to simulate embankment failure in response to swelling and shrinkage surface boundary conditions of $-10 \mathrm{kPa}$ and $-25 \mathrm{kPa}$ respectively, applied cyclically for six month intervals. Together with appropriate values of permeability this allowed cycles of approximate 'winter' and 'summer' conditions to be simulated. Nyambayo et al., (2004) showed that the permeability of the clay fill influenced the extent and magnitude of pore water pressure variation within the embankment in response to the boundary condition, and hence the number of winter and summer cycles before progressive failure. Embankments with a clay fill permeability close to $1 \times 10^{-9} \mathrm{~ms}^{-1}$ were shown to be vulnerable to the accumulation of plastic straining at the slope toe during monotonic, post-construction swelling, but not during cycles of winter and summer pore water pressure (stable after 180 cycles). In contrast, embankments with a permeability in the range $1 \times 10^{-8} \mathrm{~ms}^{-1}$ to $1 \times 10^{-7} \mathrm{~ms}^{-1}$ were shown to be stable in the short term (post-construction) but vulnerable to cyclic pore water pressure variation (failure after 37 and 11 cycles respectively) (Figure 10). This is in agreement with the critical permeability range $\left(1 \times 10^{-7} \mathrm{~ms}^{-1}\right)$ for embankment sensitivity to UK weather conditions identified by Loveridge et al., (2010).

While simplified summer and winter boundary conditions were used to assess progressive failure in railway embankments, they did not consider transient surface boundary condition 
effects which field observations have shown to influence embankment instability. They did not consider the variable duration and intensity of seasonal weather conditions (i.e. the 'wetness' or 'dryness' of a summer or winter) nor consider the influence of slope vegetation on the surface water balance of wetting and drying.

Scott et al., (2007) compared the influence of winter and summer hydraulic boundary conditions applied to a 'tree covered' and 'grass covered' LUL embankment slope using a simulation in FLAC (Itasca, 1999). The tree covered surface boundary condition included 6 month summer and winter hydraulic boundary values of $-250 \mathrm{kPa}$ and $-30 \mathrm{kPa}$ respectively while the grass covered boundary condition consisted of summer and winter hydraulic boundary values of $-100 \mathrm{kPa}$ and $0 \mathrm{kPa}$ respectively. These hydraulic boundary conditions were informed by pore water pressures measured on a LUL embankment slope which indicated that trees were able to generate large summer suctions which persisted as residual suctions during the winter months, while the grass vegetation could not. Scott et al., (2007) showed progressive failure of the grass covered slope after 35 years of simulated winter and summer cycles, the timing of which agreed with records of remedial measures at the instrumented LUL embankment. The tree covered slope simulation did not show embankment failure after 50 cycles despite a much larger cyclic pore water pressure variation than the grass covered slope. This showed that, while the presence of trees and large pore water pressure cycles reduced the strength of the fill due to ratcheting and strain softening, the residual suction $(-30 \mathrm{kPa})$ maintained by the tree during the winter condition was sufficient to maintain the stability of the slope.

Numerical modelling of climate-pore water pressure interactions was undertaken using Vadose/w (Geo-Slope, 2012) and compared with data from instrumented embankments (Briggs, 2010; O’Brien, 2013, Briggs et al., 2014). This used a daily, transient hydraulic boundary condition rather than the steady state, winter and summer hydraulic boundary 
condition applied to simulations of progressive embankment failure (Kovacevic et al., 2001; Nyambayo et al., 2004; Scott et al., 2007). A climate boundary condition incorporating daily weather data and a root water uptake function allowed the influence of climate and vegetation influences on embankment pore water pressures to be explored. The simulations were not predictive of the actual magnitude and spatial distribution of pore water pressures within an embankment, but do provide useful insights into overall patterns of behaviour and the relative importance of different variables (O'Brien, 2013). Vadose/w simulations showed that the pore water pressure response to changing weather conditions was influenced by the type of slope vegetation cover (the depth of root water uptake), the permeability of the clay fill and the variation of permeability with depth (in the near-surface soil, clay fill and foundation zones). For example, shallow rooted vegetation such as grass maintained residual suctions within a Gault Clay and a London Clay fill embankment during mild (dry) winters, but not other winters, while deep rooted vegetation such as trees maintained residual suctions at depth following extremely wet winter periods (Briggs, 2010; Briggs et al., 2014). The role of soil permeability with depth was demonstrated with simulations showing that, during the extremely wet winter of 2000/2001 (but not during less extreme years), pore water pressures increased in LUL embankments underlain by London Clay but not in those underdrained by a more permeable soil layer (Briggs, 2013a).

Rouainua et al., (2009) considered the coupled hydrological and mechanical response of a diagnostic railway embankment. Both a historical climate and a future climate change scenario were simulated. This showed an increase in the number of cycles to progressive embankment failure (increased stability) for a 2080s climate relative to the historical (2003-2006) climate. SHETRAN (Ewen et al., 2000) was used to predict pore water pressures within the slope in response to daily weather data, together with soil and vegetation inputs. Surface pore water pressures generated by the SHETRAN simulation were coupled to a strain-softening finite 
element model in FLAC (Itasca, 2002), using the same material properties as Kovacevic et al., (2001). Weather data for the climate boundary condition were generated using Earwig software (Kilsby et al., 2007) for a $5 \mathrm{~km}^{2}$ grid in Newbury, Berkshire. Twenty years of daily weather data were generated for a historical scenario (Jan 2003- Dec 2006) and for a UKCIP02 high emissions scenario in 2080 (Hulme et al., 2002). The future weather scenario considered higher temperatures and shorter, higher intensity rainfall events than the historical condition. This caused higher evapotranspiration, lower infiltration and higher run-off within the futurescenario simulation relative to the historical scenario.

Using a diagnostic embankment model, Rouainia et al., (2009) showed that climate change may not increase the rate of progressive embankment failure due to strain softening. The futurescenario showed that the embankment remained stable after a 20 -year weather cycle due to high suctions generated by the climate boundary condition. The historical scenario was less stable and showed embankment failure after five annual weather cycles. However, Rouainia et al., (2009) note that the diagnostic hydrological model did not account for surface desiccation effects induced by drying of the embankment, which can be difficult to measure (Stirling et al., 2015). The influence of surface desiccation on embankment stability is one of many uncertainties relating to changes physical processes and triggering thresholds in natural and engineered slopes in response to a changing climate (Dijkstra \& Dixon, 2010). Surface desiccation allows rapid surface water infiltration during summer rainfall events, effectively increasing the permeability of the embankment. This may alter the 2080 s simulation result by reducing the magnitude of soil suctions generated during the summer months and increasing the rate of strain softening over repeated seasonal cycles (e.g. Nyambayo et al., 2004). Changing patterns of surface cracking due to a changing climate may increase the depth of seasonal wetting and drying fronts below the surface of embankment slopes. This would 
increase the depth of significant seasonal pore water pressure cycles and changes in effective stress, which may increase embankment degradation.

\section{The research methods used to understand embankment failure}

Research to understand the failure of transport infrastructure embankments has utilised a number of different methods, applied at a range of scales (e.g. the soil, the site and the network scales). Field observations, centrifuge model testing and numerical models have been used to measure or simulate embankment behaviour; all are supported by laboratory testing and an understanding of soil behaviour (Glendinning et al., 2015).

Many embankment failures have been identified and remediated by infrastructure owners, without being reported in the literature. However, some case studies of embankment failure have been recorded both during embankment construction and their subsequent maintenance (e.g. Greenwood et al., 1985; Perry, 1989; Cooper, 1899; Squire, 1880; Garrett \& Wale, 1985; Gellatley et al., 1995; Andrei, 2000; Martin, 2000 Birch \& Dewar, 2002; O’Kelly, 2008).

Large scale surveys or the exploitation of information within infrastructure owner's databases have allowed embankment failures to be analysed at the network scale. These have identified trends in highway slope failure occurrence linked to geology (e.g. Perry, 1989; Perry, 1985; Greenwood et al., 1985; Parsons \& Perry, 1985); statistical correlations between seasonal weather, geology and railway traffic disruption (e.g. Loveridge et al., 2010) and empirical relationships between seasonal railway track movement and the presence of lineside vegetation (e.g. Briggs et al., 2013b).

Highway and railway embankment failures triggered by pore water pressure increase have been reported for individual instrumented sites (e.g. Anderson et al., 1982; Anderson \& Kneale, 1980a; Garrett \& Wale, 1985; Birch \& Dewar, 2002; Ridley et al., 2004; Briggs et al., 2013a). 
These provide field observations to inform simple embankment stability analyses (e.g. a limit equilibrium calculation). Full scale embankment model testing has been used to compare the spatial and temporal pore water response of highway and railway slopes to changing weather conditions (Toll et al., 2013; Glendinning et al., 2014; Gunn et al., 2015).

Seasonal deformation has been measured at instrumented railway embankment sites (e.g. O’Brien, 2007; Scott et al., 2007; Glendinning et al., 2009; Smethurst et al., 2015) but has not been reported for highway embankment sites. Observations have been supported by simple railway embankment deformation models based on in situ soil moisture content changes (Smethurst et al., 2015). However, more predictive models of behaviour (e.g. finite element or centrifuge models) to incorporate variables such as tree species or clay type have not been developed.

The progressive failure of embankments has been simulated assuming a strain-softening constitutive model for London Clay (Potts \& Zdravkovic, 1999; Kovacevic et al., 2001; O’Brien, 2007; Rouainia et al., 2009; O’Brien, 2013). Finite element models informed by field observations have also been used to simulate the pore water pressure response of embankments to climate and vegetation boundary conditions (Kovacevic et al., 2001; Nyambayo et al., 2004; Scott et al., 2007; Briggs, 2010; O’Brien, 2013, Briggs et al., 2014). Progressive embankment failure in response to wetting and drying cycles has been explored for different soils using centrifuge embankment models of overconsolidated kaolin and of till fill (Hudacsek et al., 2009; Take \& Bolton, 2011). However, there are limited data on which to develop a strainsoftening constitutive model for London Clay fill or for fills derived from other soil types representative of transport infrastructure embankments (e.g. Gault Clay (Mott MacDonald, 2009; O'Brien, 2013)), nor are there detailed in situ measurements from instrumented embankment sites that show progressive failure. 


\section{Conclusions}

Observations from individual instrumented earthwork sites and from the analyses of networklevel data show that the differing material composition and construction method of highway and railway embankments influences both the dominant failure mechanisms and the triggers to failure. Both highway and railway embankment failures may be triggered by changing pore water pressure conditions, however railway embankments are also susceptible to excessive deformation and/or progressive failure. The progressive failure of highway embankments has not been observed, both because highway embankments are relatively young and because they are less susceptible to seasonal pore water pressure cycling than railway embankments.

Field observations, the analysis of train delay data and simple moisture content models show that seasonal deformation is most likely to occur in railway embankments constructed from high plasticity fill with high water demand trees growing on the embankment slopes. There is a lower risk of serviceability failure due to the shrink-swell movement of highway embankments, low plasticity fill embankments or grass covered embankments.

The progressive failure of railway embankments is not well understood for the range of soil types representative of the national rail network. Progressive failure of embankment slopes has been simulated numerically based on a strain-softening assumption for London Clay. However centrifuge testing imposing cyclic wetting and drying showed a downslope ratcheting failure mechanism for an overconsolidated kaolin clay embankment slope, but much more limited seasonal displacement in a glacial till fill embankment slope. There is limited field and laboratory data to support a strain-softening constitutive model for railway fill at present, although the overall failure mechanism of progressive failure is supported by failure records and observations of 'coat-hanger' shaped embankment profiles. 
Observations at instrumented embankment sites and finite element models of embankment hydrology show that the pore water pressure regime within embankments is dominated by the interdependent influence of weather conditions, soil permeability and surface vegetation. Clay fill railway embankments with mature tree cover are susceptible to more frequent and a larger magnitude of deep pore water pressure cycling than railway embankments with grass vegetation cover or highway slopes with compacted, low permeability fill. However, lightly vegetated embankments will experience higher pore water pressures overall.

Models of embankment hydrology informed by field observations have shown the comparative influence of weather conditions, soil permeability and surface vegetation on embankment pore water pressures and soil moisture content profiles. However, these simulations may not be fully representative of future embankment deterioration or the dominant physical processes influencing pore water pressures in a changing climate (e.g. surface desiccation).

Further field and laboratory investigation is required before the routine analysis of embankment failure can rigorously accommodate many of the factors described above. However, this review shows that progress is being made to empirically identify and evaluate the various risk factors affecting transport infrastructure embankment failure.

\section{Acknowledgements}

This paper is an output from iSMART, a collaborative research project led by Newcastle University and funded by the UK Engineering and Physical Sciences Research Council (Grant number EP/K027050/01). The team gratefully acknowledges the support received from all stakeholders and academic partners. Fleur Loveridge is supported by the Royal Academy of Engineering under their Research Fellow scheme. 


\section{References}

Anderson, M.G. and Kneale, P.E., (1980a). Pore water pressure and stability conditions on a motorway embankment. Earth surface processes, 5(1), pp.37-46.

Anderson, M. G., \& Kneale, P. E. (1980b). Pore water pressure changes in a road embankment cartography. Highway Engineer,2.

Anderson, M. G., Hubbard, M. G., \& Kneale, P. E. (1982). The influence of shrinkage cracks on pore-water pressures within a clay embankment. Quarterly Journal of Engineering Geology and Hydrogeology, 15(1), 9-14.

Andrei, A. (2000). Embankment stabilisation works between Rayners Lane and South Harrow underground stations. Ground engineering, 32(10).

Arup, (2010). Highways Agency. A Risk-based framework for geotechnical asset management. Phase 2 Report, Issue 1, November 2010.

Arup, (2013). Office of Rail Regulation and Network Rail. Part A Reporter Mandate AO/030: PR13 Maintenance \& Renewals Review, Policy and WLCC Model Review. Document Ref: AO/030/02, Issue 2, June 2013.

Batchelor, A. J., Forde, M. C., \& Topping, B. H. V. (1985). Slope Failure in Low and High Plasticity Clays. In From Proceedings of the Symposium on Failures in Earthworks, organized by the Institution of Civil Engineers, held in London, March 6-7, 1985.

Birch, G. P., \& Dewar, A. L. (2002). Earthwork failures in response to extreme weather. In Proceedings of the international conference railway engineering 2002, held in London, UK, July 2002-CD ROM. 
Briggs, K. M., Smethurst, J. A., Powrie, W., \& O'Brien, A. S. (2013a). Wet winter pore pressures in railway embankments. Proceedings of the ICE-Geotechnical Engineering, 166(5), 451-465.

Briggs, K. M., Smethurst, J. A., Powrie, W., O’Brien, A. S., \& Butcher, D. J. E. (2013b). Managing the extent of tree removal from railway earthwork slopes. Ecological Engineering, 61, 690-696.

British Standards Institute, (2009). BS 6031: Code of practice for earthworks. London: British Standards Institute.

Burland, J., Chapman, T., Skinner, H.D. and Brown, M., 2012. ICE Manual of Geotechnical Engineering.

Chai, J. C., Miura, N., \& Shen, S. L. (2002). Performance of embankments with and without reinforcement on soft subsoil. Canadian Geotechnical Journal,39(4), 838-848.

Charles, J. A., \& Bromhead, E. N. (2008). Contributions to Géotechnique 1948-2008: Slope stability and embankment dams. Géotechnique, 58(5), 385-389.

Chandler, R.J. and Skempton, A.W., 1974. The design of permanent cutting slopes in stiff fissured clays. Geotechnique, 24(4), pp.457-466.

Cooper, R. E. (1899, January). Causes of earth-slips in the slopes of cuttings and embankments of railways and how to prevent or remedy them. Second Metropolitan Engineering Conference, 9 June 1899. In Minutes of the Proceedings (Vol. 138, No. 1899, pp. 383-385). Thomas Telford.

Cooper, M.R., Bromhead, E.N., Petley, D.J. and Grants, D.I., 1998. The Selborne cutting stability experiment. Géotechnique, 48(1), pp.83-101. 
Dijkstra, T. A., \& Dixon, N. (2010). Climate change and slope stability in the UK: challenges and approaches. Quarterly Journal of Engineering Geology and Hydrogeology, 43(4), 371385.

Ewen, J., Parkin, G. and O'Connell, P.E., 2000. SHETRAN: distributed river basin flow and transport modeling system. Journal of hydrologic engineering 5(3), pp.250-258.

Garrett, C., \& Wale, J. H. (1985). Performance of embankments and cuttings in Gault Clay in Kent. In From Proceedings of the Symposium on Failures in Earthworks, organized by the Institution of Civil Engineers, held in London, March 6-7, 1985.

Gellatley, M. J., Barker, D. H. \& Rankin, W. J. (1995). Interaction of vegetation with the LUL surface railway system. In Vegetation and slopes: Stabilisation, protection and ecology. Proceedings of the international conference held at the University Museum, Oxford, 29-30 September 1994.

Glendinning, S., Loveridge, F., Starr-Keddle, R. E., Bransby, M. F., \& Hughes, P. N. (2009). Role of vegetation in sustainability of infrastructure slopes.Proceedings of the ICEEngineering Sustainability, 162(2), 101-110.

Glendinning, S., Hughes, P., Helm, P., Chambers, J., Mendes, J., Gunn, D., Wilkinson, P., \& Uhlemann, S. (2014). Construction, management and maintenance of embankments used for road and rail infrastructure: implications of weather induced pore water pressures. Acta Geotechnica, 9(5), 799-816.

Glendinning, S., Helm, P.R., Rouainia, M., Stirling, R.A., Asquith, J.D., Hughes, P.N., Toll, D.G., Clarke, D., Powrie, W., Smethurst, J. and Hughes, D., 2015. Research-informed design, management and maintenance of infrastructure slopes: development of a multi-scalar 
approach. In IOP Conference Series: Earth and Environmental Science (Vol. 26, No. 1, p. 012005). IOP Publishing.

Gunn, D.A., Chambers, J.E., Uhlemann, S., Wilkinson, P.B., Meldrum, P.I., Dijkstra, T.A., Haslam, E., Kirkham, M., Wragg, J., Holyoake, S. and Hughes, P.N., 2015. Moisture monitoring in clay embankments using electrical resistivity tomography. Construction and Building Materials, 92, pp.82-94.

Greenwood, J. R., Holt, D. A., \& Herrick, G. W. (1985). Shallow slips in highway embankments constructed of overconsolidated clay. In From Proceedings of the Symposium on Failures in Earthworks, organized by the Institution of Civil Engineers, held in London, March 6-7, 1985.

Ground Engineering (1995). Change here for embankment. Ground Engineering, March 1995, pp.16-17.

Ground Engineering (2014a). Unprecedented rainfall leads to dramatic increase in Kent rail landslips. Ground Engineering, 17 February 2014.

Ground Engineering (2014b). Network Rail hopes Botley landslip repairs will be completed by mid-March. Ground Engineering, 27 February 2014, pp.16-17.

Harrison, J. W. D. (1881, January). Failures in Railway Embankments. In Minutes of the Proceedings (Vol. 66, No. 1881, pp. 258-262). Thomas Telford.

Highways Agency (2009) Manual of Contract Documents for Highway Works (MCHW), Volume 1 - Specification for Highway Works (Series 600). Highways Agency, UK 
Hudacsek, P., Bransby, M. F., Hallett, P. D., \& Bengough, A. G. (2009). Centrifuge modelling of climatic effects on clay embankments. Proceedings of the ICE-Engineering Sustainability, 162(2), 91-100.

Hughes, P. N., Glendinning, S., Mendes, J., Parkin, G., Toll, D. G., Gallipoli, D., \& Miller, P. E. (2009). Full-scale testing to assess climate effects on embankments. Proceedings of the ICE-Engineering Sustainability, 162(2), 67-79.

Itasca, F.L.A.C., 2002. Fast Lagrangian Analysis of Continua, Version 4.0 User's Guide. Itasca Consulting Group, Inc., Thrasher Square East, 708.

Kilsby, C.G., Jones, P.D., Burton, A., Ford, A.C., Fowler, H.J., Harpham, C., James, P., Smith, A. and Wilby, R.L., 2007. A daily weather generator for use in climate change studies. Environmental Modelling \& Software, 22(12), pp.1705-1719.

Kovacevic, N., Potts, D. M., \& Vaughan, P. R. (2001). Progressive failure in clay embankments due to seasonal climate changes. In Proceedings of the international conference on soil mechanics and geotechnical engineering (Vol. 3, pp. 2127-2130). AA Balkema Publishers.

Lees, A. S., MacDonald, G. J., Sheerman-Chase, A., \& Schmidt, F. (2013). Seasonal slope movements in an old clay fill embankment dam. Canadian Geotechnical Journal, 50(5), 503520.

Lehtonen, V. J., Meehan, C. L., Länsivaara, T. T., \& Mansikkamäki, J. N. (2015). Full-scale embankment failure test under simulated train loading. Géotechnique, 1-14.

Leroueil, S., 2001. Natural slopes and cuts: movement and failure mechanisms. Geotechnique, 51(3), pp.197-243. 
Li, D., Sussmann, T., Hyslip, J. and Chrismer, S., (2014). Railway Geotechnics. CRC Press, Florida, United States.

Loveridge, F. A., Spink, T. W., O'Brien, A. S., Briggs, K. M., \& Butcher, D. (2010). The impact of climate and climate change on infrastructure slopes, with particular reference to southern England. Quarterly Journal of Engineering Geology and Hydrogeology, 43(4), 461472.

Martin, J., (2000). Stabilisation of an existing railway embankment using small diameter minipiles and large diameter pin piles at Kitson Wood, Todmorden. In Proceedings of the International Conference, Railway Engineering 2000, London, UK.

Mott MacDonald (2009) Seasonal Preparedness Earthworks (TSERV 567) Final Summary Report Recommendations for Practice, Revision B June 2009, reference 244568/03/B.

Nyambayo, V. P., Potts, D. M., \& Addenbrooke, T. I. (2004). The influence of permeability on the stability of embankments experiencing seasonal cyclic pore water pressure changes. In Advances in Geotechnical Engineering. The Skempton Conference. Thomas Telford, London (pp. 898-910).

O’Brien A, Ellis EA and Russell D (2004) Old railway embankment fill: laboratory experiments, numerical modelling and field behaviour. In Advances in Geotechnical Engineering: Proceedings of the Skempton Memorial Conference, Hindhead, UK (Jardine RJ, Potts DM and Higgins KG (eds)). Thomas Telford, London, UK, vol. 2, pp. 911-921.

O'Brien A (2007) Rehabilitation of urban railway embankments: investigation, analysis and stabilisation. In Proceedings of the 14th European Conference on Soil Mechanics and Geotechnical Engineering, Madrid (Cue'llar V, Dapena E, Alonso E et al. (eds)). Millpress, Amsterdam, the Netherlands, pp. 125-143. 
O’Brien, A. S. (2013) The assessment of old railway embankments - time for a change? In Partial saturation in compacted soils: Géotechnique symposium in print 2011, 19-32 [http://dx.doi.org/10.1680/geot.sip11.ks]

O'Kelly, B.C., Ward, P.N. and Raybould, M.J., (2008). Stabilisation of a progressive railway embankment slip. Geomechanics and Geoengineering: An International Journal, 3(4).

Parsons, A. W., \& Perry, J. (1985). Slope stability problems in ageing highway earthworks. In From Proceedings of the Symposium on Failures in Earthworks, organized by the Institution of Civil Engineers, held in London, March 6-7, 1985.

Perry, J. (1985). Incidence of highway slope stability problems in Lower Lias and Weald clay. In From Proceedings of the Symposium on Failures in Earthworks, organized by the Institution of Civil Engineers, held in London, March 6-7, 1985.

Perry, J., 1989. A survey of slope condition on motorway earthworks in England and Wales. Research report-Transport and Road Research Laboratory, (199).

Perry, J., McGinnity, B., \& Russell, D. (1999). Railway earth structures: their condition, management and influence of track quality', Keynote paper. Railway Engineering, 99.

Perry, J., Pedley, M., \& Reid, M. (2003). Infrastructure embankments. C550, CIRIA: London. Potts, D.M., Kovacevic, N. and Vaughan, P.R., 1997. Delayed collapse of cut slopes in stiff clay. Géotechnique, 47(5), pp.953-982.

Potts, D.M. \& Zdravkovic, L. (1999) Finite Element Analysis in Geotechnical Engineering: Application. London, Thomas Telford Publishing.

Proctor, R.R., 1933. Fundamental principles of soil compaction. Engineering News Record, 111(9), pp.245-248. 
Ridley, A., McGinnity, B., \& Vaughan, P. (2004). Role of pore water pressures in embankment stability. Proceedings of the ICE-Geotechnical Engineering,157(4), 193-198.

Road Research Laboratory (1952). Soil Mechanics for Road Engineers. HMSO, London, 1952.

Rouainia, M., Davies, O., O'Brien, T., \& Glendinning, S. (2009). Numerical modelling of climate effects on slope stability. Proceedings of the ICE-Engineering Sustainability, 162(2), 81-89.

Scott J M, Loveridge F and O'Brien AS (2007) Influence of climate and vegetation on railway embankments. In Proceedings of the 14th European Conference on Soil Mechanics and Geotechnical Engineering, Madrid (Cue'1lar V, Dapena E, Alonso E et al. (eds)). Millpress, Amsterdam, the Netherlands, pp. 659-664.

Sharp, M., Wallis, M., Deniaud, F., Hersch-Burdick, R., Tourment, R., Matheu, E., SedaSanabria, Y., Wersching, S., Veylon, G., Durand, E. and Smith, P., (2013). The international levee handbook, C731, CIRIA, London.

Skempton, A.W., 1964. Long-term stability of slopes. Géotechnique, 14(2), pp.75-102.

Skempton AW (1996) Embankments and cuttings on the early railway. Construction History 11: $33-49$.

Smethurst, J.A., Clarke, D. and Powrie, W., 2006. Seasonal changes in pore water pressure in a grass-covered cut slope in London Clay. Géotechnique, 56(8), pp.523-537.

Smethurst, J., Briggs, K., Powrie, W., Ridley, A. and Butcher, D., 2015. Mechanical and hydrological impacts of tree removal on a clay fill railway embankment. Géotechnique , 65 (11), pp. 869-882. 
Squire, J. B. (1880, January). Earthwork slips in the cuttings and embankments of various railways, with their causes and modes of treatment. In Minutes of the Proceedings (Vol. 62, No. 1880, pp. 272-279). Thomas Telford.

Stirling, R. A., Hughes, P., Davie, C. T., \& Glendinning, S. (2015). Tensile behaviour of unsaturated compacted clay soils_-A direct assessment method. Applied Clay Science.

Symons, I F (1970). The magnitude and cost of minor instability in the side slopes of earthworks on major roads. RRL Laboratory Report LR3331. TRL Limited, Crowthorne.

Take, W. A., \& Bolton, M. D. (2011). Seasonal ratcheting and softening in clay slopes, leading to first-time failure. Géotechnique, 61(9), 757-769.

Toll, D.G., Lourenço, S.D. and Mendes, J., 2013. Advances in suction measurements using high suction tensiometers. Engineering Geology, 165, pp.29-37.

Turner S (2001) Climate change blamed as landslip incidents treble. New Civil Engineer, 10 May: 8.

Vaughan, P. R., Kovacevic, N., \& Potts, D. M. (2004). Then and now: some comments on the design and analysis of slopes and embankments. In Advances in Geotechnical Engineering. The Skempton Conference. Thomas Telford, London (pp. 241-290).

Wootton, J. (2010, August). The history of British motorways and lessons for the future. In Proceedings of the ICE-Civil Engineering (Vol. 163, No. 3, pp. 137-143). Thomas Telford. Zhang, L.L., Zhang, J., Zhang, L.M. and Tang, W.H., 2011. Stability analysis of rainfallinduced slope failure: a review. Proceedings of the ICE-Geotechnical Engineering, 164(5), pp.299-316. 


\section{Figures}

Figure 1: Embankment profile for a highway embankment (left) a railway embankment (right) (adapted from Perry et al., 2003)

Figure 2: End tipping of a Great Central Railway embankment in Whetstone around 1897 (Photo reproduced with permission of The Record Office for Leicestershire, Leicester and Rutland, on behalf of S.W.A. Newton)

Figure 3: The clod and matrix structure of dumped railway embankment fill (From O'Brien, 2007)

Figure 4a: Failure of a highway embankment slope. The compacted fill and topsoil are clearly shown (photo courtesy of David Patterson, Highways England)

Figure $4 \mathrm{~b}$ : Tension crack at the crest of a highway embankment slope (photo courtesy of David Patterson, Highways England)

Figure 5a: Failure of a railway embankment slope at Leighton Buzzard (photo courtesy of Tony Butler, Network Rail)

Figure 5b: Shallow failure of a railway embankment slope at Willow Gap on the Newcastle to Carlisle railway line (photo courtesy of David Hutchinson, Network Rail)

Figure 6: Peak wet winter pore water pressures in London Underground Ltd embankments following the wet winter of 2000/2001, categorised by foundation soil type: (a) London Clay foundation (b) chalk/river terrace deposits foundation (From Briggs et al., 2013a)

Figure 7: Seasonal track movement on a grass covered and a tree covered London Underground Ltd embankment, compared with the soil moisture deficit (SMD) (redrawn from Scott et al., 2007)

Figure 8: Midslope displacements at field scale based on centrifuge testing of model overconsolidated kaolin and glacial till fill embankments subjected to seasonal wetting and drying cycles. Solid symbols represent periods of drying and open symbols represent periods of wetting. Adapted from Take \& Bolton (2011) and Hudacsek et al., (2009).

Figure 9: Simulated horizontal embankment slope displacement in response to pore water pressure cycles for stiff fill and soft fill, with a shrinkage suction surface boundary condition $(s)$ between $5 \mathrm{kPa}$ and $20 \mathrm{kPa}$ (redrawn from Kovacevic et al., 2004)

Figure 10: Contours of sub-accumulated deviatoric plastic strain simulated for a railway embankment slope after thirteen shrink-swell cycles for (a) fill permeability $1 \times 10^{-9} \mathrm{~ms}^{-1}$ and $1 \times 10^{-8} \mathrm{~ms}^{-1}$ (b) fill permeability $1 \times 10^{-7} \mathrm{~ms}^{-1}$ (redrawn from Nyambayo et al., 2004)

\section{Tables}

Table 1: A timeline of embankment construction in the UK (adapted from Perry et al., 2003) 
Table 2: Failure mechanisms by earthwork type (adapted from Loveridge et al., 2010)

Table 3: Classification of tree water demand categories (from Briggs et al., 2013b) 
Table 1: A timeline of embankment construction in the UK (adapted from Perry et al., 2003)

\begin{tabular}{|ll|}
\hline Date & Embankment type \\
\hline circa $1800 \mathrm{~s}$ & Canal construction peak \\
1835 & Canal construction largely complete \\
1827 & Construction of the Liverpool \& Manchester Railway \\
mid $1830 \mathrm{~s}$ & Railway embankments rapidly constructed by 'end tipping' fill \\
1841 & Great Western Railway construction complete \\
$1850 \mathrm{~s}$ & Railway construction peak \\
circa 1860 & London Underground Ltd embankment construction began \\
1933 & Proctor (1933) publishes a paper on compaction \\
circa 1948 & London Underground Ltd embankments complete \\
1952 & Research into the properties of fills at the Road Research \\
& Laboratory \\
1958 & M6 Preston by-pass opened \\
1959 & M1 Motorway Watford to Crick opened \\
1986 & M25 Motorway fully opened \\
2003 & Section 1 of the Channel Tunnel Rail Link (CTRL) opened \\
\hline
\end{tabular}

Table 2: Failure mechanisms by earthwork type (adapted from Loveridge et al., 2010)

\begin{tabular}{|c|c|c|c|c|}
\hline \multirow{2}{*}{$\begin{array}{l}\text { Infrastructure } \\
\text { slope }\end{array}$} & \multicolumn{3}{|c|}{ Failure mechanism } & \multirow[t]{2}{*}{ Comment } \\
\hline & $\begin{array}{l}\text { Seasonal } \\
\text { deformation }\end{array}$ & $\begin{array}{l}\text { Pore } \\
\text { water } \\
\text { pressure } \\
\text { increase }\end{array}$ & $\begin{array}{l}\text { Progressive } \\
\text { failure }\end{array}$ & \\
\hline $\begin{array}{l}\text { Highway } \\
\text { cutting }\end{array}$ & $x$ & $\checkmark$ & $\times$ (not yet) & $\begin{array}{l}\text { Instability is rare; typically } \\
\text { occurring due to other } \\
\text { geohazards such as landslides }\end{array}$ \\
\hline $\begin{array}{l}\text { Highway } \\
\text { embankment }\end{array}$ & $x$ & $\checkmark$ & $\times($ not yet $)$ & $\begin{array}{l}\text { Highway embankments are } \\
\text { much less aged than railway } \\
\text { embankments }\end{array}$ \\
\hline $\begin{array}{l}\text { Railway } \\
\text { cutting }\end{array}$ & $x$ & $\checkmark$ & $\checkmark$ & $\begin{array}{l}\text { Many railway embankments } \\
\text { and cuttings failed during } \\
\text { construction (Skempton 1964, } \\
\text { 1996) }\end{array}$ \\
\hline $\begin{array}{l}\text { Railway } \\
\text { embankment }\end{array}$ & $\checkmark$ & $\checkmark$ & $\checkmark$ & $\begin{array}{l}\text { Network Rail manages } 50 \\
\text { earthworks failures per year } \\
\text { across Great Britain }\end{array}$ \\
\hline
\end{tabular}


Table 3: Classification of tree water demand categories (from Briggs et al., 2013b)

\begin{tabular}{|lll|}
\hline Water demand $^{\mathbf{1}}$ & Broad leaf tree species & Coniferous tree species \\
\hline High (HWD) & Oak & \\
& Poplar & \\
& Willow & \\
& Hawthorn & Cedar \\
Moderate (MWD) & Ash & Spruce \\
& Beech & Yew \\
& Cherry & Douglas Fir \\
Low (LWD) & Sycamore & \\
& Birch & \\
\hline & Holly & \\
\hline
\end{tabular}




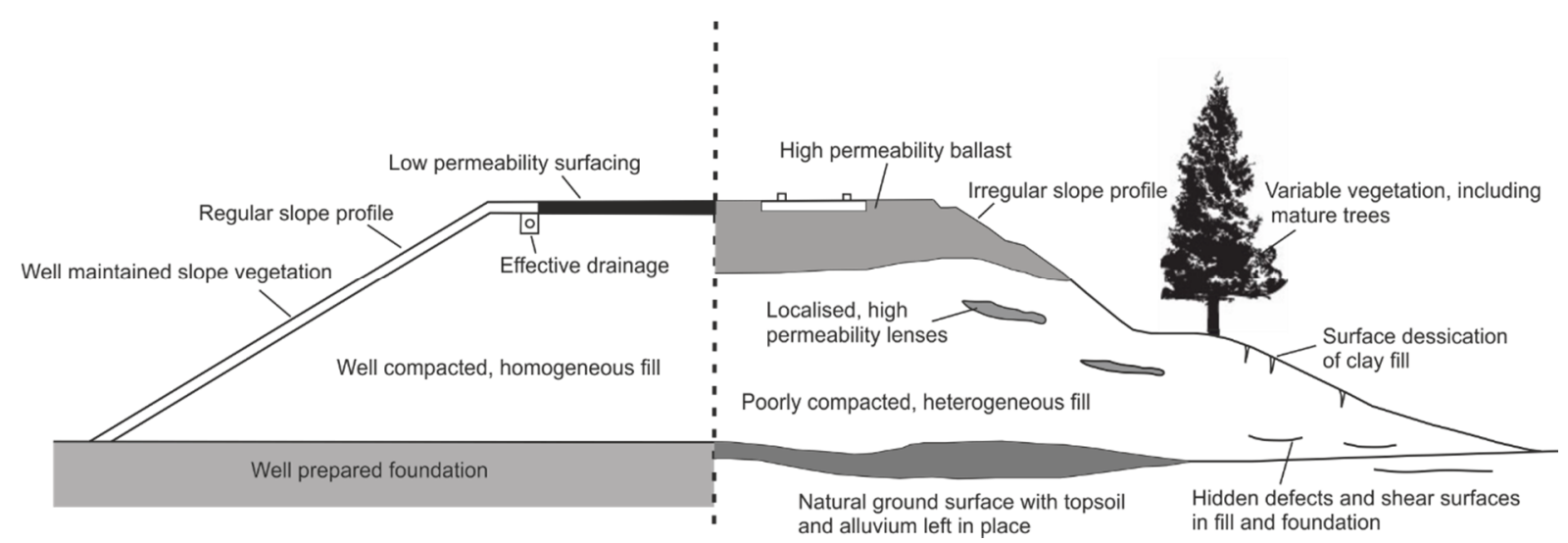

Figure 1: Embankment profile for a highway embankment (left) a railway embankment (right) (adapted from Perry et al., 2003)

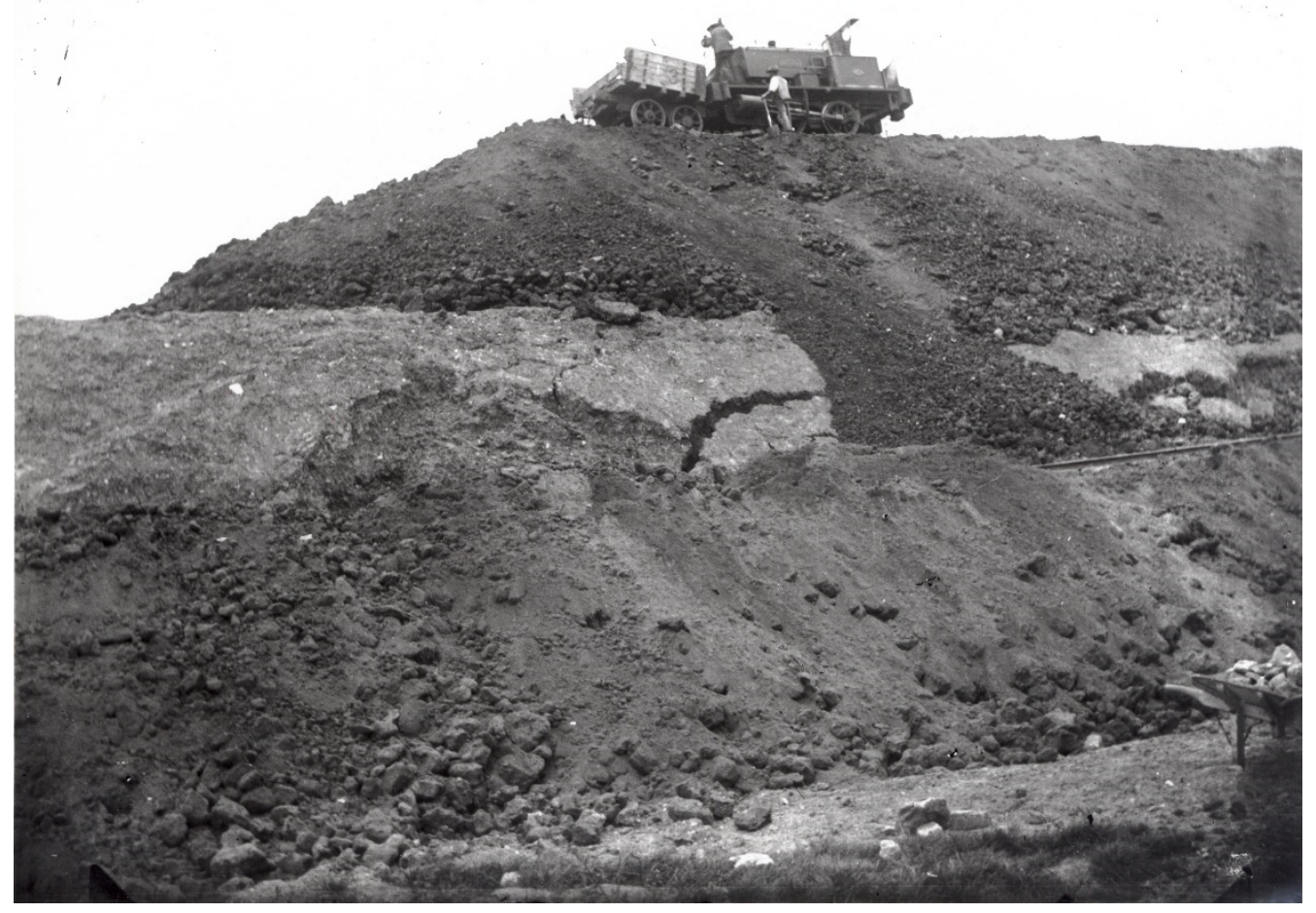

Figure 2: End tipping of a Great Central Railway embankment in Whetstone around 1897 (Photo reproduced with permission of The Record Office for Leicestershire, Leicester and Rutland, on behalf of S.W.A. Newton) 
Matrix:

- Softer

- Weaker

- More permeable

- Partly saturated

- Controls strength and permeability

Clod:

- Stiffer

- Stronger

- Less permeable

- Controls stiffness

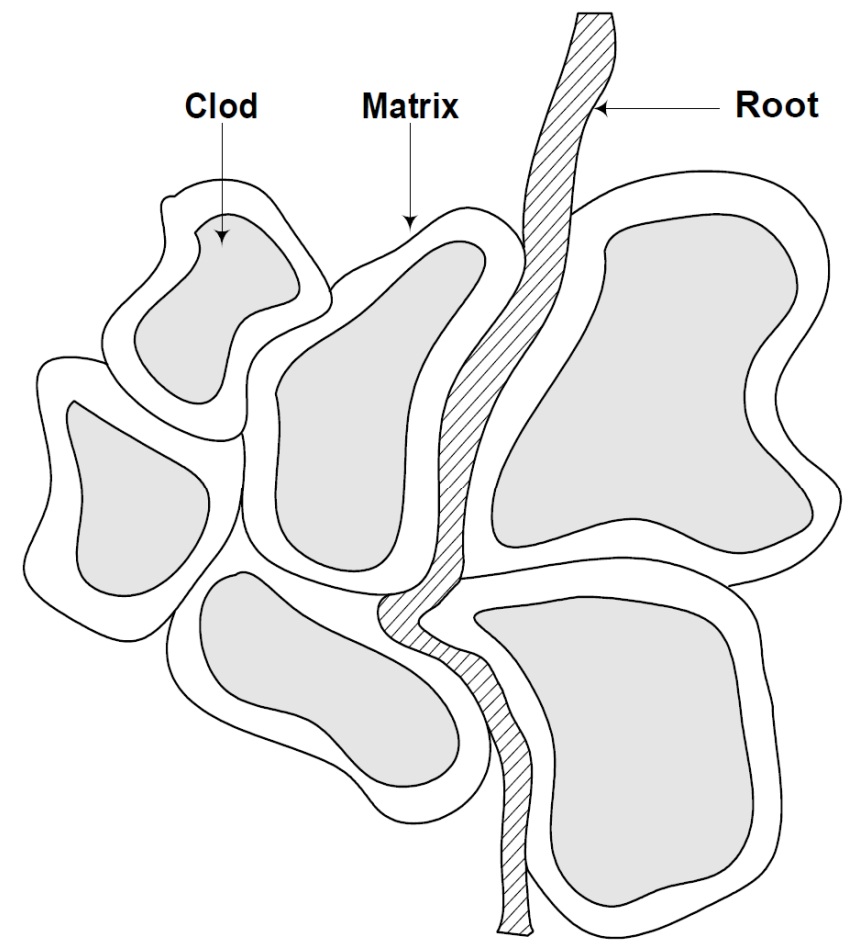

Figure 3: The clod and matrix structure of dumped railway embankment fill (From O'Brien, 2007) 


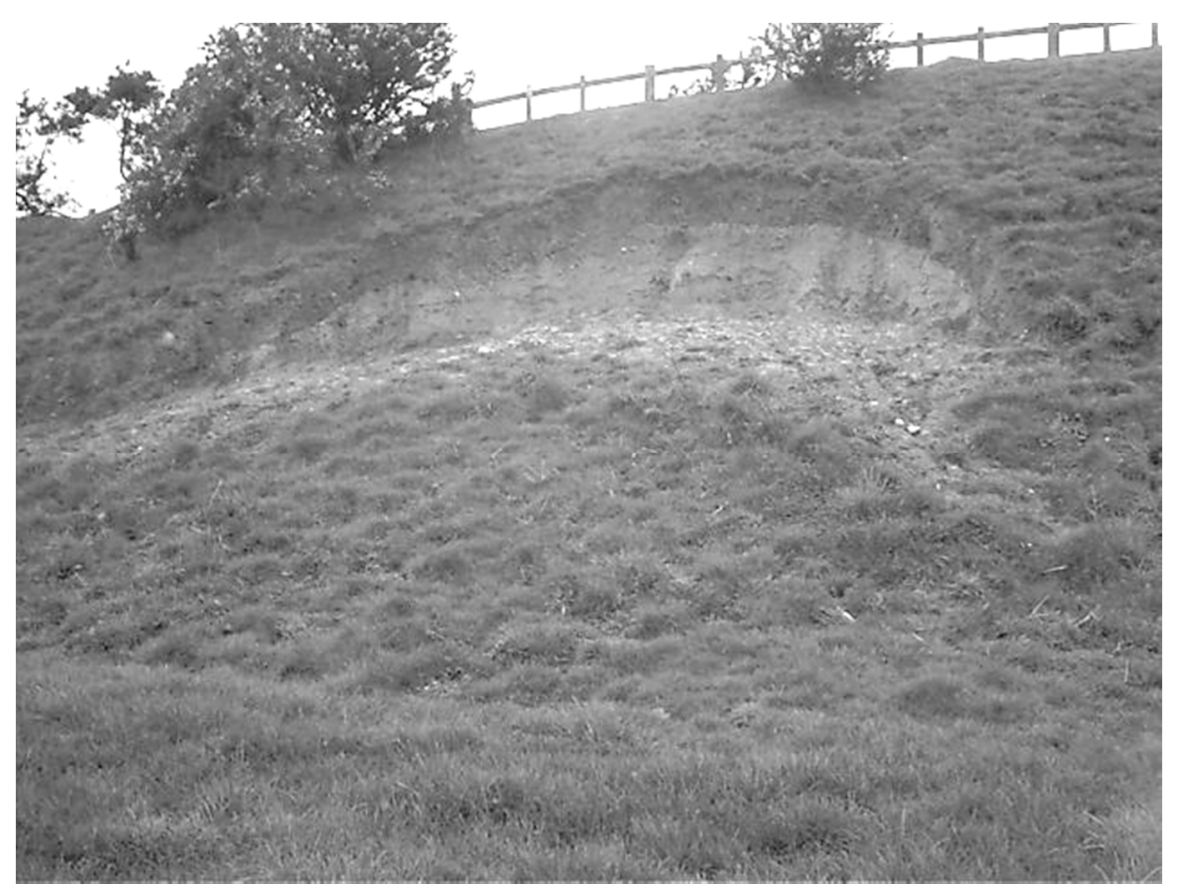

Figure 4a: Failure of a highway embankment slope. The compacted fill and topsoil are clearly shown (photo courtesy of David Patterson, Highways England)

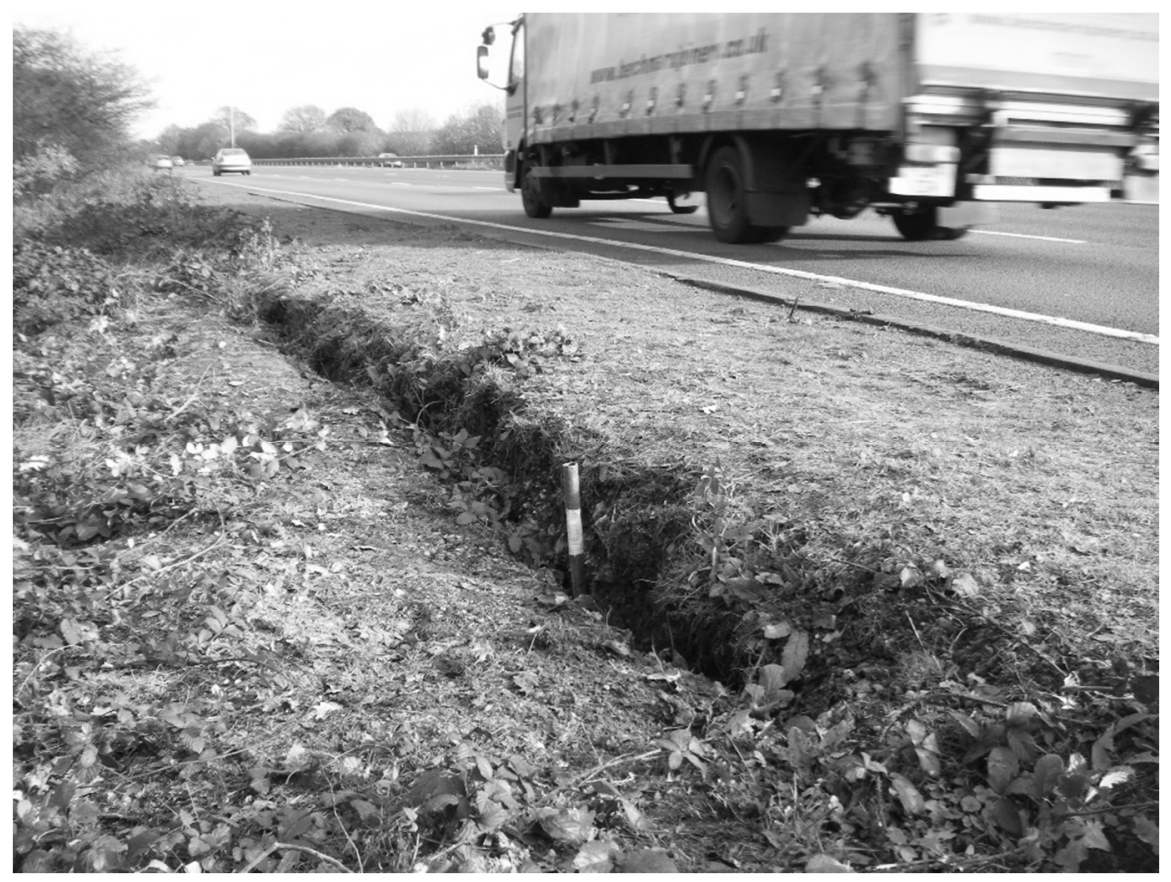

Figure 4b: Tension crack at the crest of a highway embankment slope (photo courtesy of David Patterson, Highways England) 


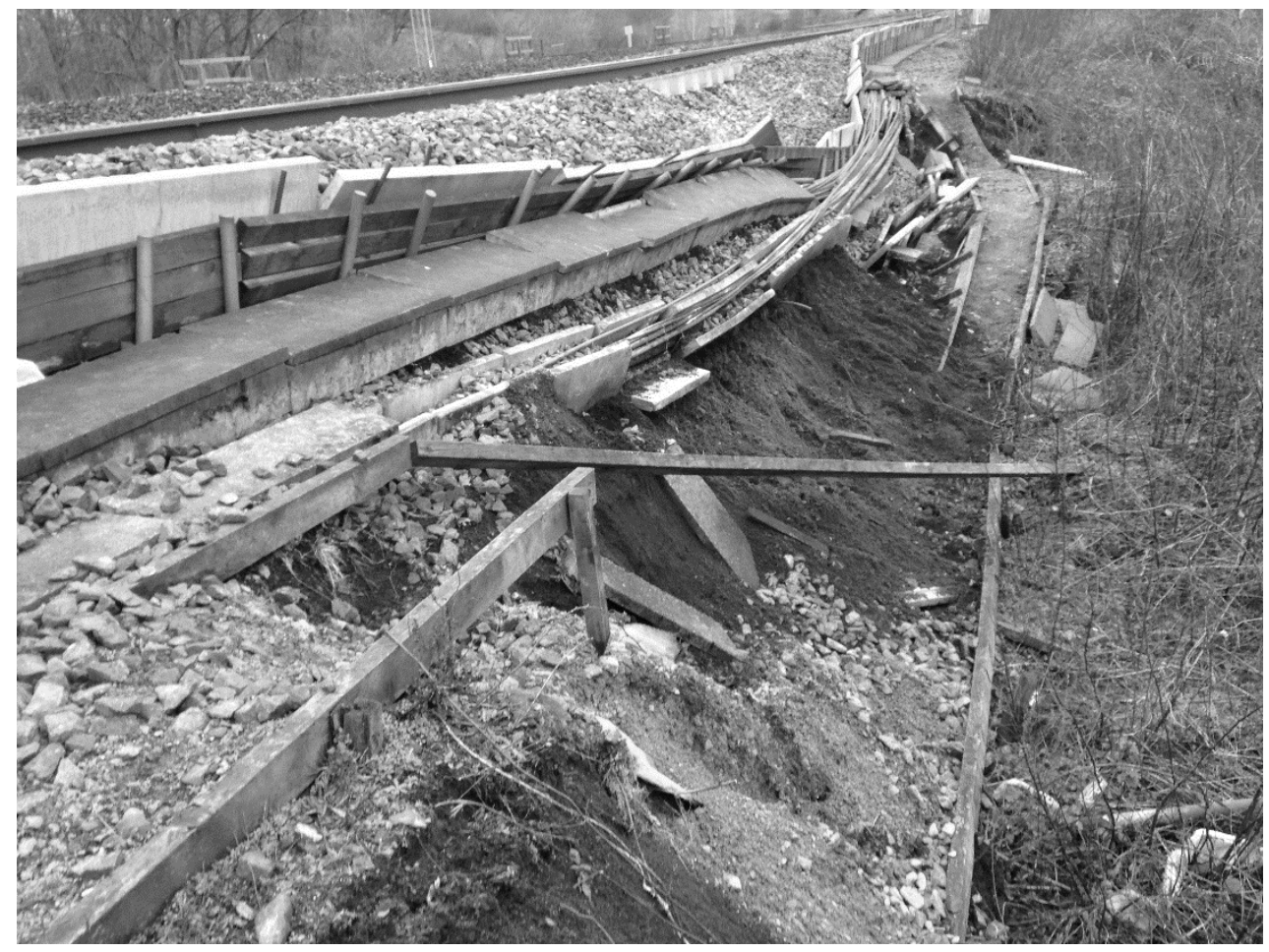

Figure 5a: Failure of a railway embankment slope at Leighton Buzzard (photo courtesy of Tony Butler, Network Rail)

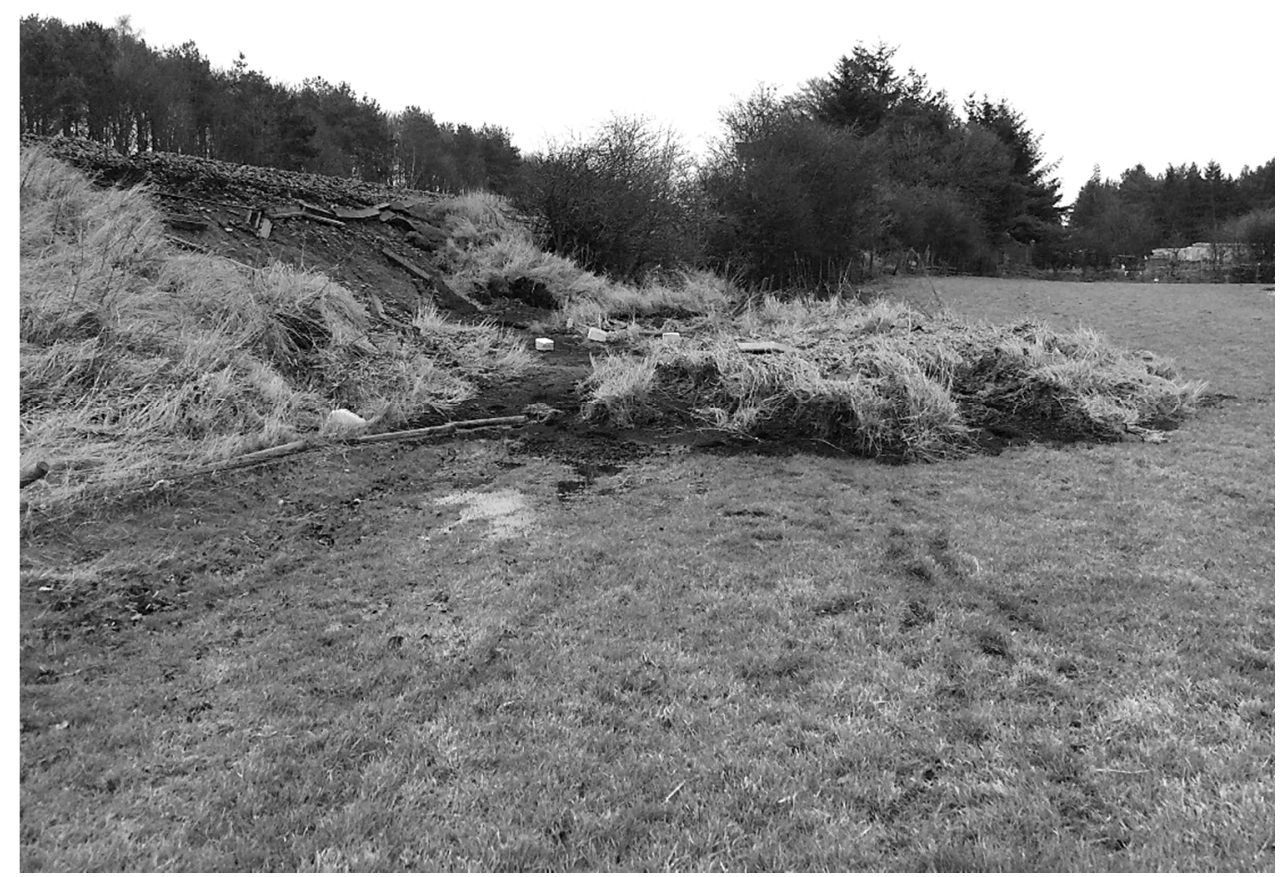

Figure 5b: Shallow failure of a railway embankment slope at Willow Gap on the Newcastle to Carlisle railway line (photo courtesy of David Hutchinson, Network Rail) 


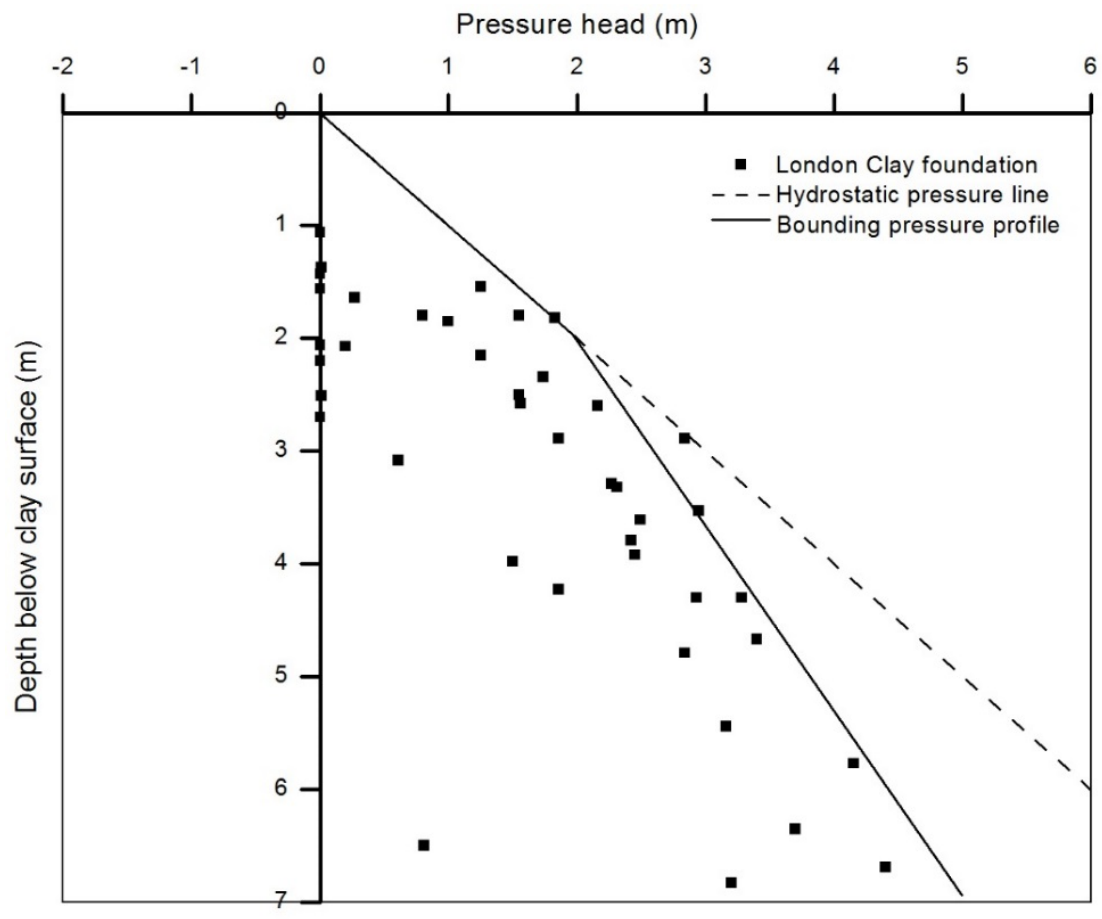

(a)

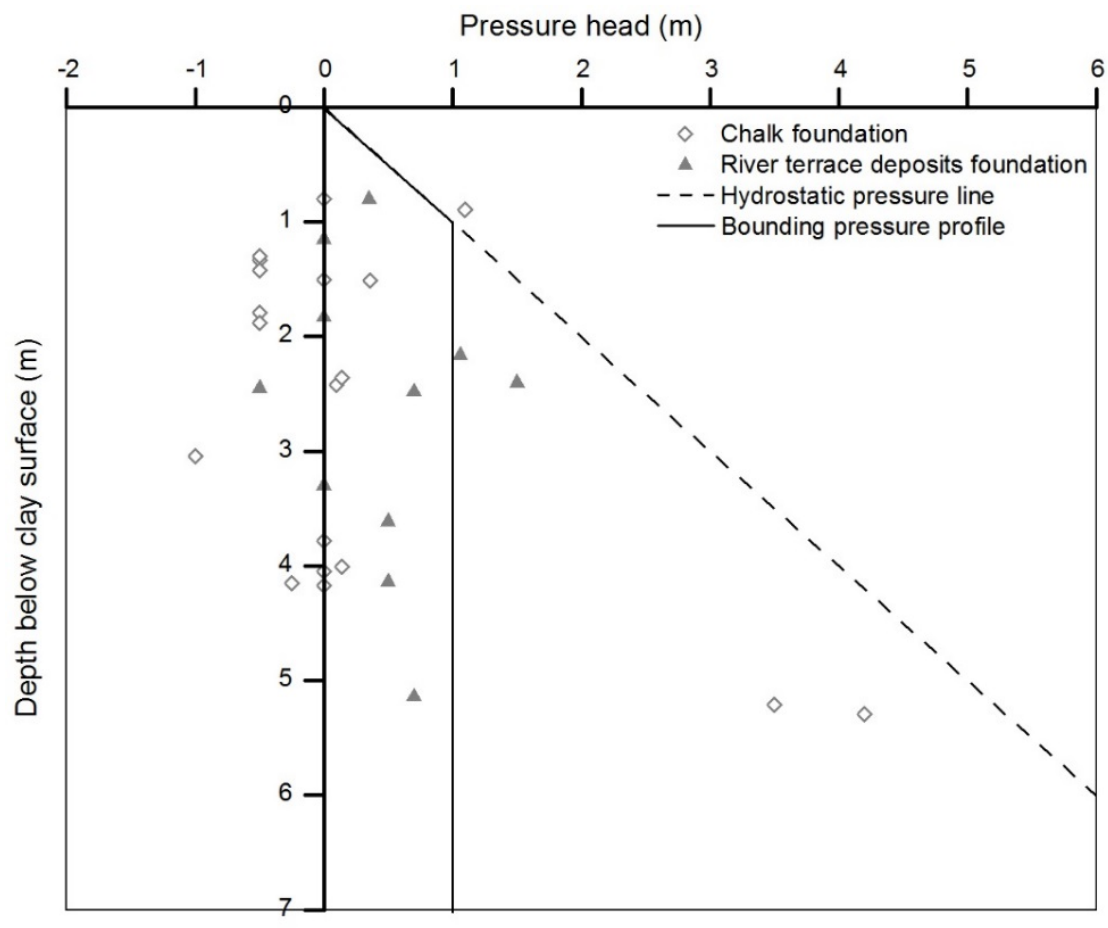

(b)

Figure 6: Peak wet winter pore water pressures in London Underground Ltd embankments following the wet winter of 2000/2001, categorised by foundation soil type: (a) London Clay foundation (b) chalk/river terrace deposits foundation (From Briggs et al., 2013a) 


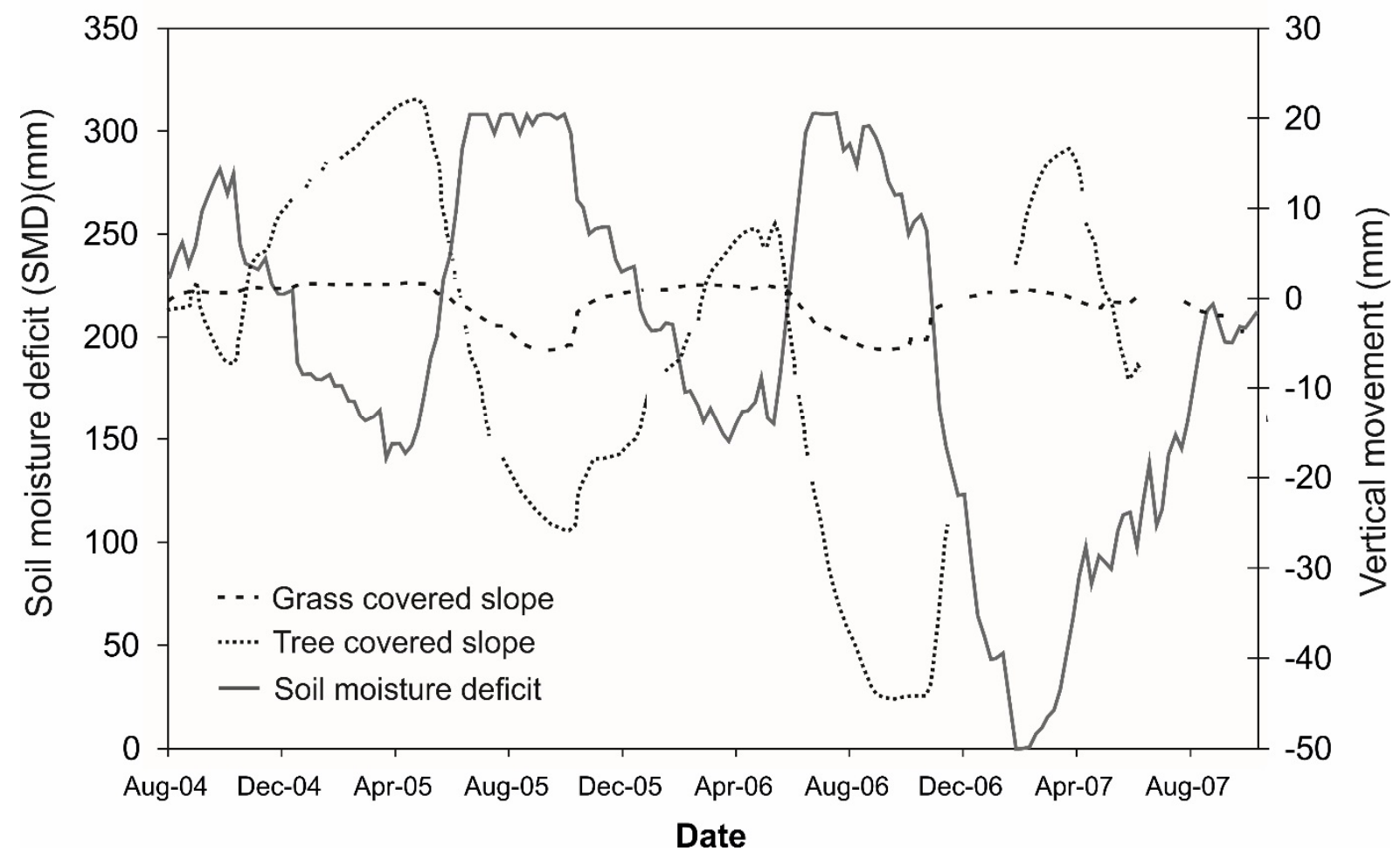

Figure 7: Seasonal track movement on a grass covered and a tree covered London Underground Ltd embankment, compared with the soil moisture deficit (SMD) (redrawn from Scott et al., 2007) 


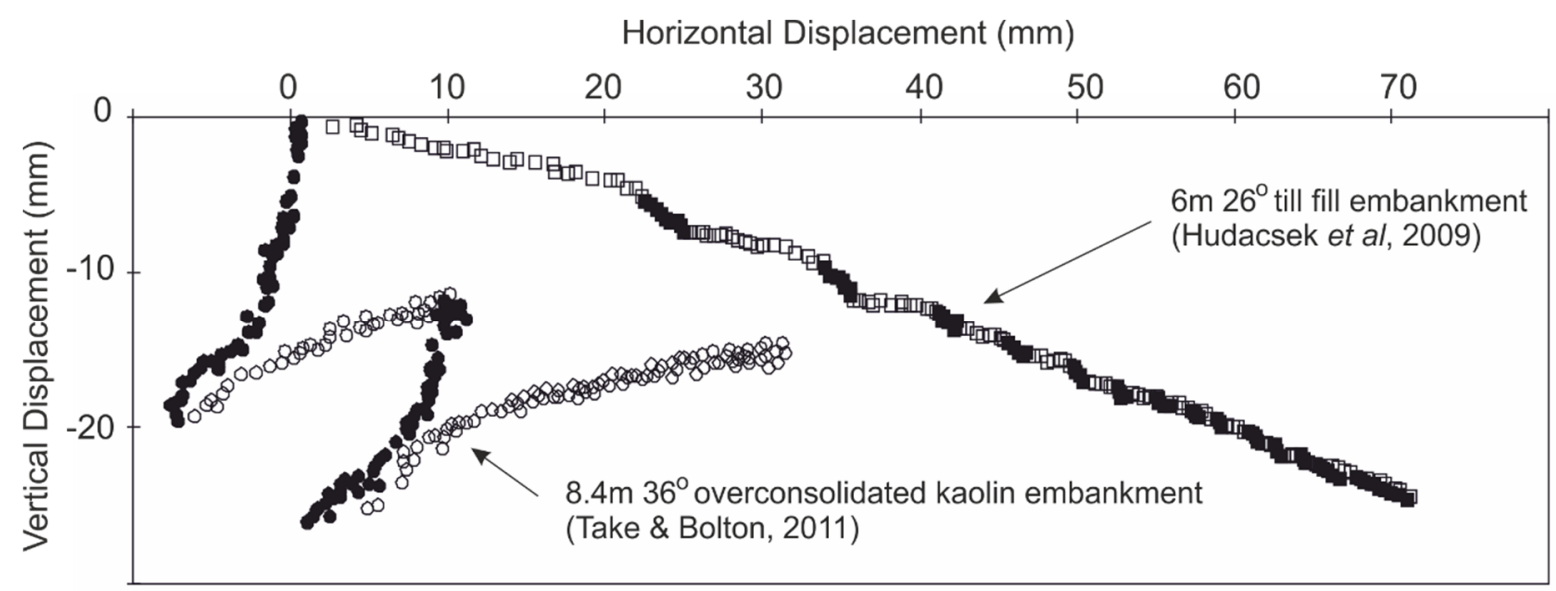

Figure 8: Midslope displacements at field scale based on centrifuge testing of model overconsolidated kaolin and glacial till fill embankments subjected to seasonal wetting and drying cycles. Solid symbols represent periods of drying and open symbols represent periods of wetting. Adapted from Take \& Bolton (2011) and Hudacsek et al., (2009). 


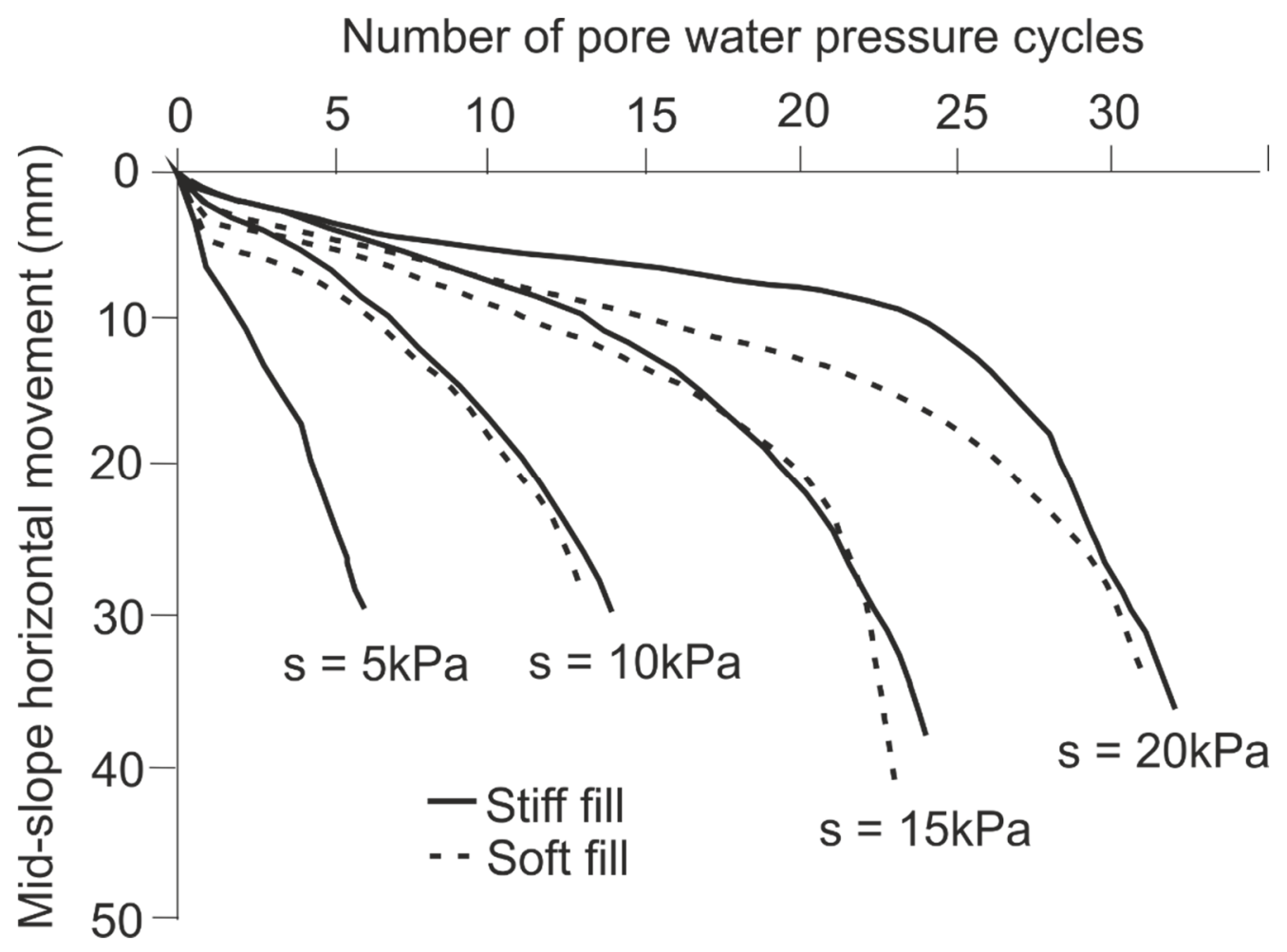

Figure 9: Simulated horizontal embankment slope displacement in response to pore water pressure cycles for stiff fill and soft fill, with a shrinkage suction surface boundary condition (s) between $5 \mathrm{kPa}$ and $20 \mathrm{kPa}$ (redrawn from Kovacevic et al., 2004) 


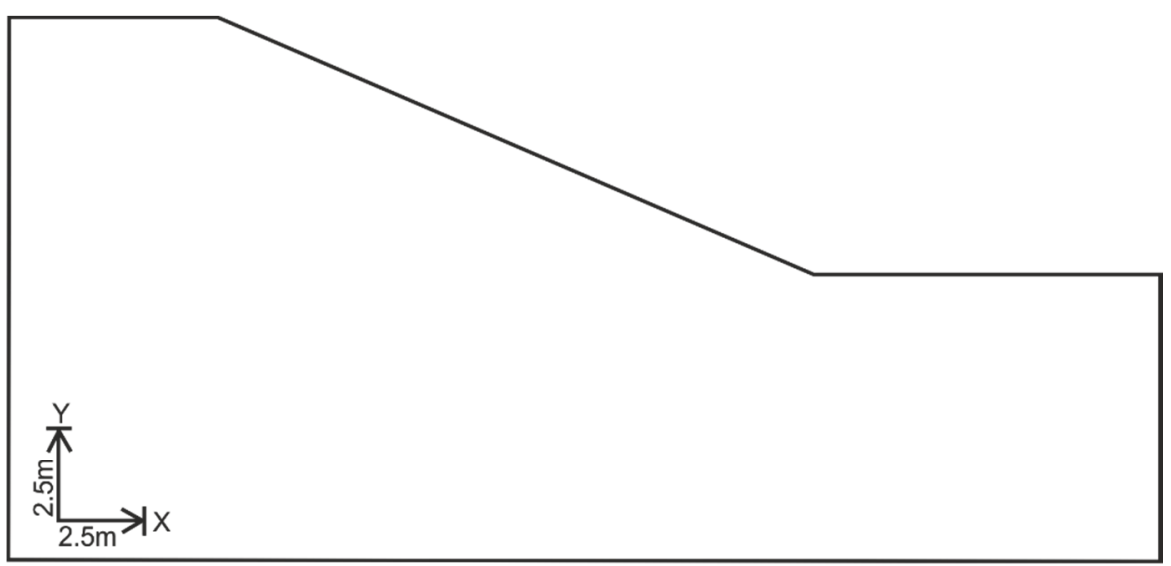

(a)

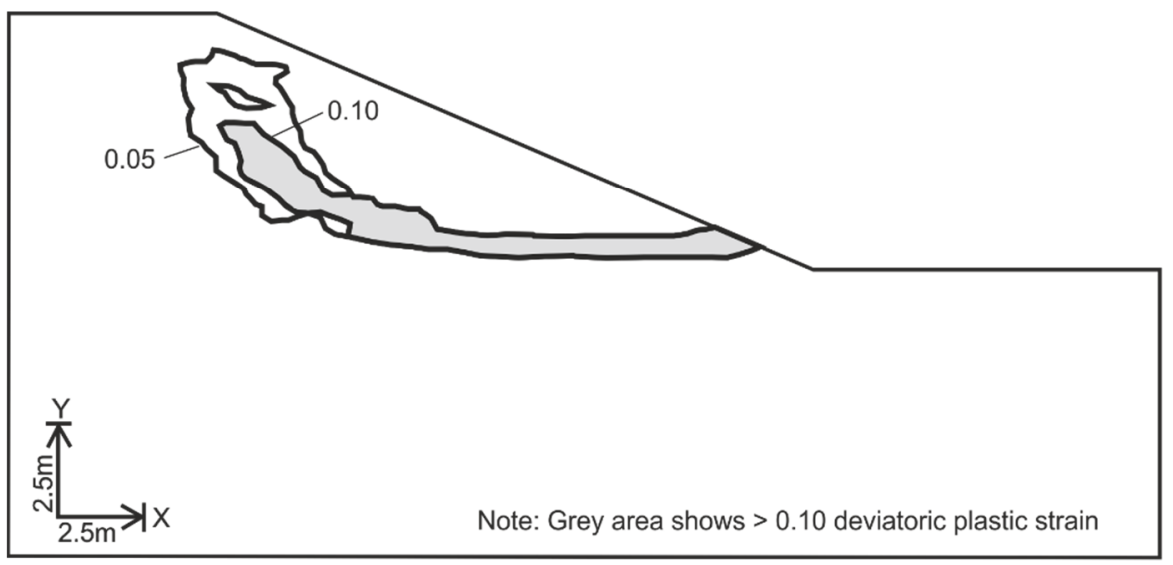

(b)

Figure 10: Contours of sub-accumulated deviatoric plastic strain simulated for a railway embankment slope after thirteen shrink-swell cycles for (a) fill permeability $1 \times$ $10^{-9} \mathrm{~ms}^{-1}$ and $1 \times 10^{-8} \mathrm{~ms}^{-1}$ (b) fill permeability $1 \times 10^{-7} \mathrm{~ms}^{-1}$ (redrawn from Nyambayo $e t$ al., 2004) 